Supplement of Hydrol. Earth Syst. Sci., 18, 5377-5397, 2014

http://www.hydrol-earth-syst-sci.net/18/5377/2014/

doi:10.5194/hess-18-5377-2014-supplement

(C) Author(s) 2014. CC Attribution 3.0 License.

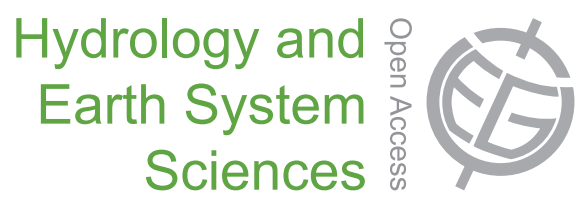

(c) (1)

Supplement of

\title{
The hydrological regime of a forested tropical Andean catchment
}

K. E. Clark et al.

Correspondence to: K. E. Clark (kathryn.clark23@gmail.com) 


\section{S1. Materials and methods}

\section{S1.1. Catchment wide rainfall estimates}

The calibration of the TRMM 3B43 v.7a data and calculation of catchment wide rainfall for the Kosñipata catchment used the following series of steps: (1) For individual meteorological stations, monthly rainfall $\left(\mathrm{mm} \mathrm{month}^{-1}\right)$ was compared to the TRMM data $\left(\mathrm{mm}\right.$ month $^{-1}$ ) and a linear regression was determined (Table S8). (2) These regression equations were used to estimate a calibrated monthly rainfall $\left(\mathrm{mm} \mathrm{month}{ }^{-1}\right)$ for the 9 meteorological stations for each TRMM month from 1998 to $2012(n=180)$. The mean annual estimated rainfall ( $\mathrm{mm} \mathrm{yr}^{-1}$ ), from adding these monthly values over each year, ranged from 1600 to $5260 \mathrm{~mm} \mathrm{yr}^{-1}$ for the various meteorological stations (Table S2). The mean monthly estimated rainfall for the study period calculated by this method coincided well with the measured meteorological station rainfall (Fig. 2a). (3) For each TRMM month $(n=180)$ another linear regression was determined between the elevation of each meteorological station and the estimated rainfall for the respective station (from step 2). (4) The elevation distribution and its proportion within each river catchment at 1 masl intervals were determined in ArcGIS at a $90 \mathrm{~m} \times 90 \mathrm{~m}$ pixel resolution using Shuttle Radar Topography Mission (SRTM) digital elevation model (DEM), using the catchment boundaries in Figure 1a. (5) For each month, the linear regression equation developed in step 3 was applied to the elevation distributions in order to estimate rainfall by month $\left(\mathrm{mm} \mathrm{month}{ }^{-1}\right)$, yielding catchment-averaged monthly rainfall estimates over the duration of the TRMM record (Fig. 4). (6) Rainfall was corrected for wind-induced rainfall losses following the method outlined in the main text and summarised in Table S3. (7) For our study period, the monthly data were summed to yield seasonal and annual estimated rainfall. The estimated catchment wide monthly rainfall data from the TRMM study period (1998 to 2012) was summed to yield annual results ( $\mathrm{mm} \mathrm{yr}^{-1}$; Table S5). Our rainfall results generally agree with rainfall estimated throughout the Andes using a correction of a TRMM 3B42 v.7 3-hourly rain rate data set with meteorological station rainfall data (Lowman and Barros, 2014).

\section{S1.2. Discharge and runoff measures}

\section{S1.2.1. Kosñipata River at the San Pedro gauging station}

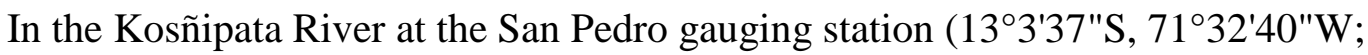
1360 masl), river velocity was measured using handheld velocity meters and, during portions of the year when it was too dangerous to enter the river, using a float method with 5 replicates (Baud et al., 2005; McMahon, 1957). Metered stream velocity was measured with a Flow Probe (Global Water FP101); this probe records average and maximum stream velocity across the full cross-section of the river. We corrected all float-measured velocities based on the regression of mean velocity and max velocity measurements. As a check on our measurements, we compared our corrected maximum velocity with a theoretical hydrodynamic velocity, adopting the Jarrett (1984) modification of Manning's Equation for mountain rivers. The slope $(S)$ of the Kosñipata channel at San Pedro is 0.04, determined independently by two methods: 1) from Quickbird orthorectified imagery and GPS waypoints 
of two different points along the river, and 2) from a LiDAR-based digital elevation model from the Carnegie Airborne Observatory (CAO) (Asner, 2014). The hydraulic radius was measured in the field, over the dry season and ranged from $R=0.40 \mathrm{~m}$ to $0.49 \mathrm{~m}(n=8)$. The difference between the empirical velocity measurements and those determined from theory using these $S$ and $R$ values ranged from $-9.7 \%$ to $13.1 \%$, with a mean difference of $0.65 \%$ ( $n$ $=7$ ). Given the range of assumptions in both the theoretical and empirical values, we view this similarity as encouraging validation of our methods.

Discharge was calculated by multiplying corrected velocity times the river crosssectional area, determined by measuring in-stream river profiles and out-of-stream bank area at low flow several times over the span of the study. Discharge and river stage height were used to construct a power-law stage-discharge rating curve for the Kosñipata River at the San Pedro gauging station $\left(n=13 ; r^{2}=0.93, P=<0.0001\right)$ :

$$
\text { Discharge }\left(\frac{m^{3}}{s}\right)=34.9952 \pm 2.3189 \times \text { Stage } h t(m)^{1.0448 \pm 0.1146}
$$

The Kosñipata River measured at the San Pedro gauging station had an almost continuous river height record for the study year, from a pressure transducer (Global Water $\mathrm{W} 16$ level logger) recording river height every 15 minutes. The instantaneous discharge associated with each height measurement was calculated using Eq (S1). During the gap in logger between mid-July and early-August, three manual river height measures were taken and linear interpolation was conducted on daily mean discharge to fill-in the gap. Monthly instantaneous discharge $\left(\mathrm{m}^{3} \mathrm{~s}^{-1}\right)$ was determined from the total monthly flow, and seasonal discharges $\left(\mathrm{m}^{3} \mathrm{~s}^{-1}\right)$ and annual discharge $\left(\mathrm{m}^{3} \mathrm{~s}^{-1}\right)$ were determined from the monthly instantaneous discharges by summing over the appropriate time periods.

Baseflow was determined for the Kosñipata River at the San Pedro gauging station using the method outlined in Gustard et al. (1992): (1) The 5-day minimum mean daily discharge was determined for non-overlapping 5 day blocks over the study period. (2) The 5day minima were multiplied by 0.9 , and if this value was less than either the preceding or subsequent 5-day minimum, it was assigned to be part of the baseflow. (3) Mean daily discharge values were linearly interpolated in between the selected 5-day minimum discharge values selected in step two. (4) If the linearly interpolated daily baseflow discharge value was less than the actual mean daily discharge value, the actual value was replaced by the interpolated value for that day. Base flow index (BFI) was calculated as the ratio of the total volume of baseflow divided by the total volume of streamflow.

\section{S1.2.2. Kosñipata River at the Wayqecha gauging station}

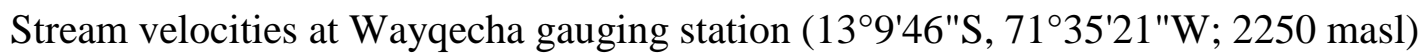
were measured using an MJP Student Stream Flow Meter as close as possible to the middle of the channel, at $75 \%$ of the total vertical depth down from the water surface, or by float method when necessary. The shallow depth and broad width of the Kosñipata at Wayqecha meant that these methods yielded indistinguishable results, and float velocities were not corrected at this site. 
At the Wayqecha station, field discharge measurements were taken weekly to monthly over the one year study period $(n=44)$, plus a two week intensive wet season study period from the end of January to mid-February 2010 ( $n=15$; Fig. 3). Four river profiles were used over the course of the study year because of the changing channel morphology, with unique power-law stage-discharge rating curves (cf. Eq. S1) used for each of the 4 river profiles. Instantaneous discharge $\left(\mathrm{m}^{3} \mathrm{~s}^{-1}\right)$ measurements were used to determine mean monthly discharge. The annual discharge was calculated as the mean of the monthly discharge rates (there were no measurements in September, so the monthly value was extrapolated linearly based on August and October). There are significant uncertainties associated with the discharge and runoff of the Kosñipata River measured at the Wayqecha gauging station, since the data comes from only 59 spot measurements throughout the year. Given the large uncertainties, the discharge data from Wayqecha is not used in the analysis in the main text but is provided at the end of this Supplement for reference.

\section{S1.3. Actual evapotranspiration estimates}

Evapotranspiration (ET) was calculated as the sum of soil evaporation $\left(L E_{\mathrm{s}}\right)$, canopy transpiration $\left(L E_{\mathrm{c}}\right)$, and evaporation of canopy intercepted water $\left(L E_{\mathrm{i}}\right)$ using the Priestley and Taylor - Jet Propulsion Laboratory (PT- JPL) model (Fisher et al., 2008). The five most important parameters for calculating ET via this method are: net radiation $\left(R_{\mathrm{n}}\right)$, normalised difference vegetation index (NDVI), soil adjusted vegetation index (SAVI), maximum air temperature $\left(T_{\max }\right)$, and water vapour pressure $(e a)$. NDVI was converted to leaf area index (LAI) and then used to predict SAVI, and minimum relative humidity $\left(R H_{\min }\right)$ and $T_{\max }$ were used to predict water vapour pressure. The PT-JPL model (Fisher et al., 2008) was applied to all meteorological stations using station-measured $R H_{\min }, T_{\max }$, and solar radiation $\left(\mathrm{R}_{\mathrm{s}}\right)$ or photosynthetically active radiation (PAR) data.

$R_{\mathrm{n}}$ was estimated from $R_{\mathrm{S}}$ or $P A R$ data (Table $\mathrm{S} 2$ ). For stations without direct $R_{S}$ data, $P A R$ was divided by 2.1 to estimate solar radiation $\left(R_{\mathrm{S}}\right)$ which is largely a conversion from $\mu \mathrm{mol}$ to PAR $\left(\mathrm{m}^{-2} \mathrm{~s}^{-1}\right)$ to total radiation $R_{\mathrm{S}}\left(\mathrm{W} \mathrm{m}^{-2}\right)$ (Monteith and Unsworth, 2013). $R_{\mathrm{n}}$ was estimated from $R_{\mathrm{s}}$ by multiplying by either 0.5 for meteorological stations in the scrubland and puna grasslands $>3450$ masl (Gilmanov et al., 2007), 0.7 for stations encompassing UMCF from 2000 to 3450 masl (Holwerda, 2005) or 0.75, a typical fraction for tropical forests (Fisher et al., 2010; Malhi et al., 2002), for stations in LMCF/LMRF ranging from 1350 to 2000 masl. The elevational ranges for each ecosystem type were determined from an ecosystem distribution map of Peru (Consbio, 2011). The vegetation type characteristic of each meteorological station is shown in Table S2. There are 2, 3, and 2 meteorological stations located in the transition/puna grasslands, UMCF, and LMCF/LMRF respectively (Table S2). Seasonal means for each meteorological station of $\mathrm{RH}_{\min }, \mathrm{T}_{\max }$, and $\mathrm{R}_{\mathrm{n}}$ were determined and the PT-JPL model was run for each station (Table S2). An NDVI of 0.85, which the PT-JPL model converted to a LAI of 5.4, was determined for the forests (transition, UMCF, LMCF, and LMRF ecosystem types) using an elevation-based linear regression (Asner et al., 2014). NDVI across the forested catchment was determined from data collected by the Carnegie Airborne Observatory (CAO) AToMS, which includes a visible-toshortwave Infrared (VSWIR) imaging spectrometer (Asner et al., 2012) with collection 
including near infrared (NIR at $800 \mathrm{~nm}$ ) and visible (VIS at $680 \mathrm{~nm}$ ) wavelengths that was used to generate high resolution NDVI data along the altitudinal gradient in the Kosñipata catchment (Asner et al., 2014). An NDVI of 0.31, which the PT-JPL model converted to a LAI of 1.0, was utilised for the puna grasslands, based on a multi-year mean of atmospheric corrected Landsat images for puna grasslands in the Kosñipata valley (Zelazowski et al., 2011).

The proportion of each elevation within the catchment was determined following Figure $2 \mathrm{c}$ in the main text; transition/puna grasslands, UMCF, and LMCF/LMRF covered $10.1,80.6$, and $8.3 \%$ of the catchment respectively. For each ecosystem type (puna/transition, UMCF, and LMCF/LMRF), AET was determined from the meteorological station AET results (Table S2). The seasonal and annual AET were determined by summing the contribution of each ecosystem type for a basin wide total.

\section{S1.4. Water isotope measurements}

Rainfall samples collected in 2010 and 2011 were collected in a rinsed plastic container left out in an open area near the San Pedro River gauging station and Wayqecha River gauging station during river water sample collection. Additional rainfall samples were taken February 2011 from elevations of 2050, 2130, 2300 and 2400 masl. Samples were transferred into $15 \mathrm{~mL}$ glass exetainers with rubber septa after filtration and stored refrigerated and unpreserved. Rain water samples from 2009 (Horwath, 2011) consisted of fresh precipitation as well as rainwater pools on leaves and were collected at elevations of 1500, 2000, 2500, 3000, and 3600 masl over the course of $~ 1$ week in April 2009, in July 2009, and in September 2009 (Table S4a).

Cloud water vapour samples are from Horwath (2011) and were collected below the tree canopy using a 'double action hand pump' (Galert) to draw ambient air into a cryogenic trap (liquid $\mathrm{N}_{2}$ ) continuously over the course of 15-20 minutes. Cloud vapour samples were collected at the same elevations and during the same time periods as the rainwater with the exception that there were no cloud water vapour samples collected during April 2009.

River water samples were collected from the river surface with a clean polypropylene graduated cylinder, filtered onsite with a $0.2 \mu \mathrm{m}$ nylon filter, and stored unpreserved in a 60 $\mathrm{mL}$ HDPE bottles. To test the suitability of storing the samples in HDPE bottles, a subset of the samples were also collected into $15 \mathrm{~mL}$ glass exetainers with rubber septa after filtration and stored unpreserved. Upon returning the laboratory, all of the samples were stored at $3^{\circ} \mathrm{C}$ until analysis. Comparisons between the two different collection methods (i.e. HDPE bottles vs. glass exetainers) did not reveal any systematic differences and agreed within the analytical uncertainties.

Isotopic analyses of water samples were performed with a Picarro L1102-i cavity ring down spectrometer (CRDS) at the University of Southern California or at the University of Cambridge. Values are reported in delta notation relative to the VSMOW standard where: 


$$
\delta D=\left(\left(\frac{D / H_{\text {sample }}}{D / H_{\text {VSMOW }}}\right)-1\right) * 1000
$$

161

162

163

and

$$
\delta^{18} O=\left(\left(\frac{{ }^{18} O /{ }^{16} O_{\text {sample }}}{{ }^{18} O /{ }^{16} O_{\text {VSMOW }}}\right)-1\right) * 1000
$$

Both the average value and the standard deviation of the replicate injections are reported in Tables S4, S6 \& S9. Isotopic analyses of river water samples collected in glass exetainers were performed with either a Los-Gatos DLT-100 Liquid Water Isotope Analyzer at the California Institute of Technology or a Delta V Advantage IRMS equipped with a Gasbench II system at the University of Oxford. These analyses were used to check the accuracy of the Picarro CRDS results.

\section{S1.5. Water isotope mixing model}

Only the samples collected in the Kosñipata River at the San Pedro gauging samples were used in the mixing calculations, because there is a noticeable isotopic offset between the samples from the San Pedro gauging station and the Wayqecha gauging station (Tables S6 \& S7). The isotopic offset is most likely the result of the different sampling elevations, but it is not possible to separate quantitatively the effect of elevation on the isotopic composition of rainfall with our data. Using the isotopic composition of small streams draining only a narrow range of elevations with our study site, Ponton et al. (2014) calculated isotopic lapse rates for $\delta \mathrm{D}$ of $-17 \pm 3 \% \mathrm{~km}^{-1}$ and $-22 \pm 2 \% \mathrm{~km}^{-1}$ for dry and wet season conditions respectively. Using the difference in the median elevation between the two catchments, these lapse rates predict a $\delta \mathrm{D}$ offset of $8.5 \pm 1.5 \%$ or $11 \pm 1 \%$ for dry or wet season conditions respectively. Broadly, these predicted offsets are consistent with our data. However, because the timescale over which the small streams integrate the isotopic composition of precipitation is unknown (i.e. the mean and distribution of transit times), it is not possible to robustly use these lapse rates to extend our mixing calculations to the Wayqecha catchment.

We used an isotope mixing model on Kosñipata River samples from the San Pedro gauging station to distinguish contributions to river runoff from wet season rainfall, dry season rainfall, and cloud water. In order to use the water isotope data to make quantitative estimates of the water sources to river flow, three end-member isotopic mixing was simulated with the mixing equations:

$$
\begin{array}{r}
\delta D_{\text {river }}=f_{1}\left(\delta D_{1}\right)+f_{2}\left(\delta D_{2}\right)+f_{3}\left(\delta D_{3}\right) \\
D x s_{\text {river }}=f_{1}\left(D x s_{1}\right)+f_{2}\left(D x s_{2}\right)+f_{3}\left(D x s_{3}\right)
\end{array}
$$

and

$$
1=f_{1}+f_{2}+f_{3}
$$


where

$$
D x S_{\text {river }}=\delta D_{\text {river }}-\left(\delta^{18} O_{\text {river }} \times 8\right)
$$

192

To calculate the mixing proportions (i.e. $f_{1}, f_{2}$, and $f_{3}$ ), the matrix inversion function of MATLAB 2013a was used. Due to the observed variability in the three end-members (Fig. 5 in main text), which is known to significantly influence the results of end-member mixing calculations (Phillips and Gregg, 2001), 10,000 random end-member $\delta$ D and Dxs values were generated using the observed ranges for each end-member. For each sample, the mixing proportions were determined for all of the 10,000 end member combinations, but only a fraction of the combinations (18-72\%) yielded plausible results (i.e. mixing proportions between 0 and 1$)$. The mean, $5^{\text {th }}$ percentile, $50^{\text {th }}$ percentile, and $95^{\text {th }}$ percentile of all possible $(0 \leq \Sigma \mathrm{f} \leq 1)$ mixing proportions are presented in Table $\mathrm{S} 7$. The effect of the analytical uncertainty on the individual rainwater samples on the calculated mixing proportions was considered by generating 1000 pseudo-random synthetic data for each sample and determining the mixing portions for each of the 10,000 end member combinations (i.e. $10^{7}$ simulations per sample). For each sample, the pseudo-random values were generated from a normal distribution with the measured sample mean and standard deviation. To assess whether or not $10^{7}$ simulations per sample yielded re-producible results given the large number of possible end-member and sample composition combinations, replicate model calculations using different randomly generated datasets for the same input parameters were performed. These replicate calculations yielded between 0.1 and $5 \%$ variation in the statistical parameters (i.e. mean, median, and $5^{\text {th }}$ and $95^{\text {th }}$ percentiles) of the distribution of fractional contributions for each end-member.

End-member compositions were defined based on observed precipitation data for selected time intervals. The wet season rainfall end-member was determined based on the average and standard deviation of the December 2010, March 2010, January 2011, February 2011, and March 2011 rainwater data (Fig. 5). For dry season precipitation, the average and standard deviation of the September 2009, July 2009, June 2010, and June 2011 rainwater data was used. The cloud water vapour was defined by the average and standard deviation of the July and September 2009 cloud water data, which was the only available data (Table S4b).

\section{S2. Results}

\section{S2.1. Isotopic analyses}

Rainwater $\delta \mathrm{D}$ and $\delta^{18} \mathrm{O}$ values display considerable seasonal variation whereas variation with elevation during a given season is less pronounced (Table S4a; Fig. S1). Rainwater $\delta \mathrm{D}$ and $\delta^{18} \mathrm{O}$ values are enriched during the dry season. Kosñipata rainwaters defined the local meteoric water line (LMWL, the relationship between $\delta \mathrm{D}$ and $\delta^{18} \mathrm{O}$ in precipitation; Fig. S1) defined by $\delta \mathrm{D}=8.6561 \times \delta^{18} \mathrm{O}+21.119$, close to the global meteoric water line (GMWL) of $\delta \mathrm{D}=8.20 \times \delta^{18} \mathrm{O}+11.27$ (Rozanski et al., 1993; Craig, 1961). In 
southern Ecuador the LMWL was found to be even closer to the GMWL (Windhorst et al., 2013). Dxs, which is the deviation from the GMWL, shows minimal seasonal variation in the Kosñipata rainfall samples (Fig. 5).

The Kosñipata cloud water vapour has similar $\mathrm{dD}$ and $\delta^{18} \mathrm{O}$ to rainwater (Fig. S1) probably because of the orographic mechanism of cloud formation at this site (Scholl et al., 2011). Kosñipata cloud water has slightly depleted $\delta^{18} \mathrm{O}$ and slightly enriched $\delta \mathrm{D}$ (i.e. higher Dxs, by $>+20 \%$ ) compared to the LMWL. The deviation of cloud water from the LMWL is probably due to local water recycling (Horwath, 2011; Froehlich et al., 2002). The higher and more variable Dxs of the cloud water vapour samples separates this cloud source from the rainfall samples and is the main isotopic characteristic that allows them to be differentiated in the mixing model (Fig. S1; Table S4b). Dxs has been used as a tool to evaluate water recycling in other tropical montane cloud forests (Scholl et al., 2007; Rhodes et al., 2006) and tropical forests such as the Amazon (Martinelli et al., 1996; Salati et al., 1979), to evaluate the sources of fog (Liu et al., 2007), and to evaluate the contribution of seasonal precipitation to streamflow (Guswa et al., 2007), but as far as we are aware, this is its first use as a fingerprint of cloud inputs to streamflow.

Streamwater samples fall along the LMWL, suggesting that evaporation most likely is not a major determinant of stream water isotopic composition (Fig. S1). This is consistent with similar $\mathrm{Cl}$ concentrations in rainwater $(2-20 \mu \mathrm{M})$ and streamflow $(2-12 \mu \mathrm{M})$ (Torres et al., in review). Stream water isotopes in the Kosñipata River are consistent with other samples measured from the Amazon and Andes (Lambs et al., 2012; Lambs et al., 2007), i.e. they are similar to values previously measured from high Andean sites that are relatively depleted compared to the lowland Amazon due to Rayleigh distillation during orographic rain-out (Gat, 1996).

\section{S2.2. Results from the Wayqecha gauging station}

\section{S2.2.1. Catchment wide rainfall}

The Kosñipata sub-basin of Wayqecha had a lower catchment wide rainfall than the larger catchment at San Pedro (Table S5). This was apparent in the distribution of rainfall throughout the catchment (Fig. 2d) and reflects variation in annual rainfall as a function of elevation (Table S2). Seasonal differences suggest that the wet season is slightly more dominant in the Wayqecha sub-basin ( $+4 \%$ compared to the same period in the larger basin measured at the San Pedro gauging station) and that the dry season rainfall is slightly more dominant in the larger basin measured at the San Pedro gauging station ( $+3 \%$ compared to the same period in the Wayqecha sub-basin; Tables $2 \& \mathrm{~S} 10$ ).

\section{S2.2.2. Discharge and runoff}

The Wayqecha sub-basin in the Kosñipata catchment, with a mean elevation 3195 masl and an area of $48.5 \mathrm{~km}^{2}$, was estimated to have a mean annual discharge of $4.7 \mathrm{~m}^{3} \mathrm{~s}^{-1}$ with an annual runoff of $3065 \mathrm{~mm} \mathrm{yr}^{-1}\left(8.4 \mathrm{~mm} \mathrm{~d}^{-1}\right.$; Table S10). The catchment had a 
seasonal range in monthly mean values of 2.3 to $8.8 \mathrm{~m}^{3} \mathrm{~s}^{-1}$ (4.1 to $14.1 \mathrm{~mm} \mathrm{~d}^{-1}$ ). There are significant uncertainties in these annual totals for the Wayqecha station as they are based on only 59 spot measurements of discharge. The seasonal variation in flow was greater in amplitude at the Wayqecha gauge (Table S10) than compared to that of the San Pedro river gauge (Table 2). This suggests that the discharge and runoff in the sub-basin of Wayqecha follows a similar pattern to the larger Kosñipata catchment measured at San Pedro, but may be subjected to more short-term variation.

\section{S2.2.3. Water isotopes at Wayqecha station}

277

At the Kosñipata River gauging station at Wayqecha, $\delta \mathrm{D}$ and $\delta^{18} \mathrm{O}$ values were more depleted than at the Kosñipata River gauging station at San Pedro as a result of altitude effects on water isotope ratios (cf. Lambs et al. (2012)). At the Wayqecha gauging station, values for $\delta \mathrm{D}, \delta^{18} \mathrm{O}$, and Dxs ranged from -107.0 to $-88.9 \%,-15.9$ to $-13.5 \%$, and 18.3 to $20.5 \%$ (Table S9). Relative to samples collected in the Kosñipata River at the San Pedro gauging station, seasonality in the Kosñipata River at the Wayqecha gauging station was less pronounced.

\section{S2.2.4. Water budget for Wayqecha}

The inputs for the headwater basin (Wayqecha) are estimated at $2750 \mathrm{~mm} \mathrm{yr}^{-1}$ (wind286 loss corrected rainfall at $2519 \mathrm{~mm} \mathrm{yr}^{-1}$ and assuming CWI at $232 \mathrm{~mm} \mathrm{yr}^{-1}$ based on estimated

287 CWI for the San Pedro gauging station). The outputs are $3709 \mathrm{~mm} \mathrm{yr}^{-1}$, with runoff at 3065 $288 \mathrm{~mm} \mathrm{yr}^{-1}$ and AET at $643 \mathrm{~mm} \mathrm{yr}^{-1}$ (Table S10). Thus, outputs exceeded inputs by $960 \mathrm{~mm} \mathrm{yr}^{-1}$ $289(35 \%)$, in part due to the very large uncertainties particularly on estimated discharge for this 290 sub-catchment. 


\section{References for supplementary information}

293

ACCA: Weather data San Pedro station, Asociación para la concervación de la cuenca Amazónica http://atrium.andesamazon.org/index.php, (last access: April 2012), 2012.

Asner, G. P., Knapp, D. E., Boardman, J., Green, R. O., Kennedy-Bowdoin, T., Eastwood, M., Martin, R. E., Anderson, C., and Field, C. B.: Carnegie Airborne Observatory-2: Increasing science data dimensionality via high-fidelity multi-sensor fusion, Remote Sens. Environ., 124, 454-465, http://dx.doi.org/10.1016/i.rse.2012.06.012, 2012.

Asner, G. P.: unpublished data, 2014.

Asner, G. P., Anderson, C. B., Martin, R. E., Knapp, D. E., Tupayachi, R., Sinca, F., and Malhi, Y.: Landscape-scale changes in forest structure and functional traits along an Andes-to-Amazon elevation gradient, Biogeosciences, 11, 843-856, http://dx.doi.org/10.5194/bg-11-843-2014, 2014.

Baud, O., Hager, W. H., and Minor, H. E.: Toward nonintrusive flood discharge measurement, J. Hydraul. Eng., 131, 1031-1035, http://dx.doi.org/10.1061/(ASCE)07339429(2005)131:12(1031), 2005.

Consbio: Ecosistemas Terrestres de Peru (Data Basin Dataset) for ArcGIS, The Nature Conservancy/NatureServe Covallis, Oragon, USA, (last access: April 2012), 2011.

Craig, H.: Standard for Reporting Concentrations of Deuterium and Oxygen-18 in Natural Waters, Science, 133, 1833-1834, http://dx.doi.org/10.1126/science.133.3467.1833, 1961.

Fisher, J. B., Tu, K. P., and Baldocchi, D. D.: Global estimates of the land-atmosphere water flux based on monthly AVHRR and ISLSCP-II data, validated at 16 FLUXNET sites, Remote Sens. Environ., 112, 901-919, http://dx.doi.org/10.1016/j.rse.2007.06.025, 2008.

Fisher, J. B., Whittaker, R. J., and Malhi, Y.: ET come home: potential evapotranspiration in geographical ecology, Global Ecol. Biogeogr., 20, 1-18, http://dx.doi.org/10.1111/j.14668238.2010.00578.x, 2010.

Froehlich, K., Gibson, J. J., and Aggarwal, P.: Deuterium excess in precipitation and its climatological significance, Proceeding of Study of Environmental Change Using Isotope Techniques, Vienna, Austria, 23-27 April 2001, IAEA-CSP-13/P, 54-66, 2002.

Gat, J. R.: Oxygen and hydrogen isotopes in the hydrologic cycle, Annu. Rev. Earth PI. Sc., 24, 225262, 1996.

Gilmanov, T. G., Soussana, J. F., Aires, L., Allard, V., Ammann, C., Balzarolo, M., Barcza, Z., Bernhofer, C., Campbell, C. L., Cernusca, A., Cescatti, A., Clifton-Brown, J., Dirks, B. O. M., Dore, S., Eugster, W., Fuhrer, J., Gimeno, C., Gruenwald, T., Haszpra, L., Hensen, A., Ibrom, A., Jacobs, A. F. G., Jones, M. B., Lanigan, G., Laurila, T., Lohila, A., G.Manca, Marcolla, B., Nagy, Z., Pilegaard, K., Pinter, K., Pio, C., Raschi, A., Rogiers, N., Sanz, M. J., Stefani, P., Sutton, M., Tuba, Z., Valentini, R., Williams, M. L., and Wohlfahrt, G.: Partitioning European grassland net ecosystem $\mathrm{CO}_{2}$ exchange into gross primary productivity and ecosystem respiration using light response function analysis, Agr Ecosyst Environ, 121, 93-120, http://dx.doi.org/10.1016/j.agee.2006.12.008, 2007.

Girardin, C. A. J., Silva-Espejo, J. E., Doughty, C. E., Huaraca Huasco, W., Metcalfe, D. B., Durand-Baca, L., Marthews, T. R., Aragao, L. E. O. C., Farfan Rios, W., García Cabrera, K., Halladay, K., Fisher, J. B., Galiano-Cabrera, D. F., Huaraca-Quispe, L. P., Alzamora-Taype, I., Equiluz-Mora, L., Salinas-Revilla, N., Silman, M., Meir, P., and Malhi, Y.: Productivity and carbon allocation in a tropical montane cloud forest of the Peruvian Andes, Plant Ecology and Diversity, 7, 107123, http://dx.doi.org/10.1080/17550874.2013.820222, 2014.

Gustard, A., Bullock, A., and Dixon, J.: Low flow estimation in the United Kingdom, Low flow estimation in the United Kingdom, Institute of Hydrology, Wallingford, UKpp., 1992. 
Guswa, A. J., Rhodes, A. L., and Newell, S. E.: Importance of orographic precipitation to the water resources of Monteverde, Costa Rica, Adv Water Resour, 30, 2098-2112, http://dx.doi.org/10.1016/i.advwatres.2006.07.008, 2007.

Holwerda, F.: Water and energy budgets of rain forests along an elevation gradient under maritime tropical conditions, PhD, Earth Sciences, VU University, Amsterdam, The Netherlands, 167 pp., 2005.

Holwerda, F., Burkard, R., Eugster, W., Scatena, F., Meesters, A., and Bruijnzeel, L.: Estimating fog deposition at a Puerto Rican elfin cloud forest site: comparison of the water budget and eddy covariance methods, Hydrol Process, 20, 2669-2692, http://dx.doi.org/10.1002/hyp.6065, 2006.

Horwath, A.: Epiphytic bryophytes as cloud forest indicators: Stable isotopes, biomass and diversity along an altitudinal gradient in Peru, Doctor of Philosophy, Plant Sciences, University of Cambridge, Cambridge, 260 pp., 2011.

Huaraca Huasco, W., Girardin, C. A. J., Doughty, C. E., Metcalfe, D. B., Baca, L. D., Silva-Espejo, J. E., Cabrera, D. G., Aragão, L. E. O., Davila, A. R., Marthews, T. R., Huaraca-Quispe, L. P., Alzamora-Taype, I., Eguiluz-Mora, L., Farfan-Rios, W., Cabrera, K. G., Halladay, K., SalinasRevilla, N., Silman, M., Meir, P., and Malhi, Y.: Seasonal production, allocation and cycling of carbon in two mid-elevation tropical montane forest plots in the Peruvian Andes, Plant Ecology and Diversity, 1-2, 125-142, http://dx.doi.org/10.1080/17550874.2013.819042, 2014.

Jarrett, R. D.: Hydraulics of high-gradient streams, J. Hydraul. Eng., 110, 1519-1539, 1984.

Lambs, L., Muller, E., and Fromard, F.: The Guianese paradox: How can the freshwater outflow from the Amazon increase the salinity of the Guianan shore?, J. Hydrol., 342, 88-96, http://dx.doi.org/10.1016/j.jhydrol.2007.05.022, 2007.

Lambs, L., Horwath, A., Otto, T., Julien, F., and Antoine, P. O.: Isotopic values of the Amazon headwaters in Peru: comparison of the wet upper Río Madre de Dios watershed with the dry Urubamba-Apurimac river system, Rapid Commun. Mass Sp., 26, 775-784, http://dx.doi.org/10.1002/rcm.6157, 2012.

Liu, W. J., Liu, W. Y., Li, P. J., Gao, L., Shen, Y. X., Wang, P. Y., Zhang, Y. P., and Li, H. M.: Using stable isotopes to determine sources of fog drip in a tropical seasonal rain forest of Xishuangbanna, SW China, Agr. Forest Meteorol., 143, 80-91, http://dx.doi.org/10.1016/i.agrformet.2006.11.009, 2007.

Lowman, L. E. L., and Barros, A. P.: Investigating Links between Climate and Orography in the central Andes: Coupling Erosion and Precipitation using a Physical-statistical Model, J Geophys ResEarth, http://dx.doi.org/10.1002/2013JF002940, 2014.

Malhi, Y., Pegoraro, E., Nobre, A. D., Pereira, M. G. P., Grace, J., Culf, A. D., and Clement, R.: Energy and water dynamics of a central Amazonian rain forest, J. Geophys. Res., 107, 8061, http://dx.doi.org/10.1029/2001JD000623, 2002.

Martinelli, L. A., Victoria, R. L., Sternberg, L. S. L., Ribeiro, A., and Moreira, M. Z.: Using stable isotopes to determine sources of evaporated water to the atmosphere in the Amazon basin, J Hydrol., 183, 191-204, http://dx.doi.org/10.1016/0022-1694(95)02974-5, 1996.

McMahon, J. P.: DDT-treatment of rivers for eradication of Simuliidae, B. World Health Organ., National Center for Biotechnology Information, Bethesda MD, USA, 541 pp., 1957.

Monteith, J. L., and Unsworth, M. H.: Principles of environmental physics: Plants, animals, and the atmosphere, Academic Press, Oxford, UK, 357 pp., 2013.

Phillips, D. L., and Gregg, J. W.: Uncertainty in source partitioning using stable isotopes, Oecologia, 127, 171-179, http://dx.doi.org/10.1007/s004420000578, 2001.

Ponton, C., West, A. J., Feakins, S. J., and Galy, V.: Leaf wax biomarkers in transit record river catchment composition, Geophys Res Lett, 41, http://dx.doi.org/10.1002/2014GL061328, 2014. 
Rapp, J. M., and Silman, M. R.: Diurnal, seasonal, and altitudinal trends in microclimate across a tropical montane cloud forest, Clim. Res., 55, 17-32, http://dx.doi.org/10.3354/cr01127, 2012.

Rhodes, A. L., Guswa, A. J., and Newell, S. E.: Seasonal variation in the stable isotopic composition of precipitation in the tropical montane forests of Monteverde, Costa Rica, Water Resour. Res., 42, W11402, http://dx.doi.org/10.1029/2005WR004535, 2006.

Rozanski, K., Araguás-Araguás, L., and Gonfiantini, R.: Isotopic Patterns in Modern Global Precipitation, in: Climate Change in Continental Isotopic Records, edited by: Swart, P. K., Lohman, K. C., McKenzie, J., and Savin, S., American Geophysical Union, Washington, DC, 136, 1993.

Salati, E., Dall'Olio, A., Matsui, E., and Gat, J. R.: Recycling of water in the Amazon basin: an isotopic study, Water Resour. Res., 15, 1250-1258, http://dx.doi.org/10.1029/WR015i005p01250, 1979.

Scholl, M., Eugster, W., and Burkard, R.: Understanding the role of fog in forest hydrology: stable isotopes as tools for determining input and partitioning of cloud water in montane forests, Hydrol. Process., 25, 353-366, http://dx.doi.org/10.1002/hyp.7762, 2011.

Scholl, M. A., Giambelluca, T. W., Gingerich, S. B., Nullet, M. A., and Loope, L. L.: Cloud water in windward and leeward mountain forests: The stable isotope signature of orographic cloud water, Water Resour. Res., 43, W12411, http://dx.doi.org/10.1029/2007WR006011, 2007.

SENAMHI: Clima: Datos históricos Peru, http://www.senamhi.gob.pe/main mapa.php?t=dHi, (last access: May 2012), 2012.

Torres, M. A., West, A. J., and Clark, K. E.: Geomorphic regime modulates hydrologic control of chemical weathering in the Andes-Amazon, Geochim Cosmochim Ac, in review.

Windhorst, D., Waltz, T., Timbe, E., Frede, H. G., and Breuer, L.: Impact of elevation and weather patterns on the isotopic composition of precipitation in a tropical montane rainforest, Hydrol. Earth Syst. Sci., 17, 409-419, http://dx.doi.org/10.5194/hess-17-409-2013, 2013.

Zelazowski, P., Sayer, A. M., Thomas, G. E., and Grainger, R. G.: Reconciling satellite-derived atmospheric properties with fine-resolution land imagery: Insights for atmospheric correction, J Geophys Res-Atmos, 116, http://dx.doi.org/10.1029/2010JD015488, 2011. 


\section{Supplementary tables}

423

TABLE S1: Catchment-wide mean monthly estimated rainfall ( $\left.\mathrm{mm} \mathrm{month}^{-1}\right) 1998$ to 2012 showing seasonality.

\begin{tabular}{|c|c|c|c|c|c|c|c|c|c|c|c|c|}
\hline $\begin{array}{l}\text { Kosñipata } \\
\text { catchment } \\
\text { measured } \\
\text { at: }\end{array}$ & Jan. & Feb. & March & April & May & June & July & Aug. & Sept. & Oct. & Nov. & Dec. \\
\hline San Pedro & $399 \pm 43$ & $411 \pm 64$ & $416 \pm 41$ & $218 \pm 20$ & $135 \pm 14$ & $130 \pm 13$ & $135 \pm 14$ & $129 \pm 12$ & $156 \pm 15$ & $208 \pm 23$ & $224 \pm 23$ & $317 \pm 39$ \\
\hline Wayqecha & $338 \pm 40$ & $351 \pm 57$ & $355 \pm 38$ & $171 \pm 18$ & $94 \pm 13$ & $91 \pm 12$ & $94 \pm 13$ & $89 \pm 11$ & $114 \pm 14$ & $162 \pm 22$ & $177 \pm 22$ & $262 \pm 36$ \\
\hline Months & 15 & 15 & 15 & 15 & 15 & 15 & 15 & 15 & 15 & 15 & 15 & 15 \\
\hline Season* & wet & wet & wet & wet-dry & dry & dry & dry & dry & dry & dry-wet & dry-wet & wet \\
\hline
\end{tabular}

${ }^{*}$ Rainfall patterns indicate that the wet season runs from December to March (green), the wet-dry transition season runs throughout April (blue), the dry season runs from May until September (yellow), and the dry-wet transition season runs through October and November (red). Rainfall is corrected for wind-induced loss. Uncertainties are $2 \times$ standard error.

424 


\begin{tabular}{|c|c|c|c|c|c|c|c|c|c|c|c|c|c|c|c|c|}
\hline $\begin{array}{l}\# \text { in } \\
\text { Fig. } \\
1 a^{\circ}\end{array}$ & $\begin{array}{l}\text { Meteor- } \\
\text { ological } \\
\text { station }\end{array}$ & Gauge type & $\begin{array}{c}\text { Elev- } \\
\text { ation } \\
\text { (masl) }\end{array}$ & $\begin{array}{c}\text { Lat/long } \\
\text { coordinates } \\
(\mathrm{S}, \mathrm{W})\end{array}$ & $\begin{array}{c}\text { Land } \\
\text { cover type }\end{array}$ & $\begin{array}{r}\text { Landscape } \\
\text { e description } \\
\end{array}$ & $\begin{array}{c}\text { Aspect } \\
\left({ }^{\circ}\right)^{\wedge \wedge}\end{array}$ & $\begin{array}{l}\text { Slope } \\
\left({ }^{\circ}\right)^{\wedge}\end{array}$ & $\begin{aligned} & T_{\max } \\
& n \quad\left({ }^{\circ} \mathrm{C}\right) \\
&\end{aligned}$ & $\begin{array}{c}R H_{\text {min }} \\
(\%)\end{array}$ & $\begin{array}{c}R_{\mathrm{n}} \\
\left(\mathrm{W} \mathrm{m}^{-2}\right)\end{array}$ & $\begin{array}{c}\text { Meteor- } \\
\text { ological } \\
\text { station } \\
\text { annual } \\
\text { rainfall (mm } \\
\left.\mathrm{yr}^{-1}\right) \\
\end{array}$ & $\begin{array}{c}\text { TRMM calibrated } \\
\text { rainfall } \\
\text { (corrected } \\
\text { rainfall) from } \\
1998 \text { to } 2012 \\
\left(\mathrm{~mm} \mathrm{yr}^{-1}\right) \\
\end{array}$ & AET & $\mathrm{AET}_{\mathrm{i}}$ & $\mathrm{AET}_{\mathrm{C}}$ \\
\hline \multirow{2}{*}{1} & Acjanaco & manual & \multirow{2}{*}{3460} & \multirow{2}{*}{$\begin{array}{l}13^{\circ} 11^{\prime} 45.674 ", \\
71^{\circ} 37^{\prime} 14.818^{\prime \prime}\end{array}$} & \multirow{2}{*}{$\begin{array}{l}\text { Puna } \\
\text { grassland }\end{array}$} & \multirow{2}{*}{$\begin{array}{l}\text { Rolling } \\
\text { mountain } \\
\text { top }\end{array}$} & \multirow{2}{*}{140} & \multirow{2}{*}{8.6} & 7912.1 & $65.0^{\wedge}$ & $\mathrm{N} / \mathrm{A}$ & $1908^{a}$ & $1800(1845)$ & $\mathrm{N} / \mathrm{A}$ & $\mathrm{N} / \mathrm{A}$ & $\mathrm{N} / \mathrm{A}$ \\
\hline & Acjanaco $^{h}$ & $\begin{array}{l}\text { Skye } \\
\text { Instruments }\end{array}$ & & & & & & & 1211.6 & 76.1 & $74^{\#}$ & 1698 & $\mathrm{~N} / \mathrm{A}$ & 710 & 104 & 250 \\
\hline 2 & TU 3450 & $\begin{array}{l}\text { Smart } \\
\text { Sensors/ } \\
\text { HOBO }\end{array}$ & 3450 & $\begin{array}{l}\text { 136'48.749", } \\
71^{\circ} 36^{\prime} 27.306^{\prime \prime}\end{array}$ & $\begin{array}{l}\text { Transition } \\
\text { /Scrub- } \\
\text { land }\end{array}$ & $\begin{array}{l}\text { Rolling } \\
\text { mountain } \\
\text { top/peak of } \\
\text { a mountain } \\
\text { ridge }\end{array}$ & 356 & 26.7 & 1611.9 & 72.3 & $62^{* \mathrm{e}}$ & $2148^{b}$ & 2516 (2579) & 470 & 175 & 274 \\
\hline 3 & Wayqecha & $\begin{array}{l}\text { Campbell } \\
\text { a Scientific }\end{array}$ & 2900 & $\begin{array}{l}13^{\circ} 11^{\prime} 18.434 ", \\
71^{\circ} 35^{\prime} 9.667^{\prime \prime}\end{array}$ & UMCF & $\begin{array}{l}\text { Mountain } \\
\text { slope just } \\
\text { below tree } \\
\text { line, far } \\
\text { from ridge }\end{array}$ & 122 & 32.8 & 4516.2 & 70.0 & $78^{* f}$ & $1752^{c}$ & $1600(1640)$ & 652 & 190 & 435 \\
\hline 4 & TU 2750 & $\begin{array}{l}\text { Smart } \\
\text { Sensors/ } \\
\text { HOBO }\end{array}$ & 2750 & $\begin{array}{l}13^{\circ} 6^{\prime} 18.537^{\prime \prime}, \\
71^{\circ} 35^{\prime} 22.26^{\prime \prime}\end{array}$ & UMCF & $\begin{array}{l}\text { Mountain } \\
\text { ridge }\end{array}$ & 319 & 28 & 1916.0 & 75.7 & $82^{\star^{f}}$ & $2940^{b}$ & 3154 (3233) & 696 & 262 & 402 \\
\hline 5 & Rocotal & manual & 2090 & $\begin{array}{l}13^{\circ} 6^{\prime} 47.575 ", \\
71^{\circ} 34^{\prime} 14.673^{\prime \prime}\end{array}$ & UMCF & $\begin{array}{l}\text { Mountain } \\
\text { slope near } \\
\text { road }\end{array}$ & 70.5 & 32.9 & 9720.6 & $76.4^{\wedge}$ & $\mathrm{N} / \mathrm{A}$ & $4140^{\mathrm{a}}$ & $4152(4256)$ & $\mathrm{N} / \mathrm{A}$ & $\mathrm{N} / \mathrm{A}$ & $\mathrm{N} / \mathrm{A}$ \\
\hline 6 & TU 1800 & $\begin{array}{l}\text { Smart } \\
\text { Sensors/ } \\
\text { HOBO }\end{array}$ & 1850 & $\begin{array}{l}\text { 134'11.331", } \\
71^{\circ} 33^{\prime} 30.215^{\prime \prime}\end{array}$ & LMCF & $\begin{array}{l}\text { Mid - } \\
\text { mountain } \\
\text { slope }\end{array}$ & 321 & 30.6 & 1820.3 & 72.4 & $100^{\star 9}$ & $4116^{b}$ & 3998 (4098) & 916 & 308 & 567 \\
\hline \multirow[t]{2}{*}{7} & $\begin{array}{l}\text { San } \\
\text { Pedro }\end{array}$ & $\begin{array}{l}\text { Vantage Pro } \\
2 \text { Plus, Davis } \\
\text { Instruments }\end{array}$ & 1450 & $\begin{array}{l}13^{\circ} 3^{\prime 2} 21.219^{\prime \prime} \\
71^{\circ} 32^{\prime} 48.841^{\prime \prime}\end{array}$ & LMRF & \multirow[t]{2}{*}{$\begin{array}{l}\text { Mountain } \\
\text { slope near } \\
\text { the river }\end{array}$} & 183 & 13.6 & \multirow[t]{2}{*}{1323.7} & \multirow[t]{2}{*}{77.0} & \multirow[t]{2}{*}{$98^{\# g}$} & \multirow[t]{2}{*}{$5436^{d}$} & \multirow[t]{2}{*}{4831 (4952) } & \multirow[t]{2}{*}{1008} & \multirow[t]{2}{*}{328} & \multirow[t]{2}{*}{631} \\
\hline & $\begin{array}{l}\text { San } \\
\text { Pedro }\end{array}$ & $\begin{array}{l}\text { Skye } \\
\text { Instruments }\end{array}$ & 1360 & $\begin{array}{l}\text { 13³'20.191", } \\
\text { 71'32'38.305" }\end{array}$ & LMRF & & 183 & 4 & & & & & & & & \\
\hline
\end{tabular}




\begin{tabular}{|c|c|c|c|c|c|c|c|c|c|c|c|c|c|c|c|c|}
\hline 8 & SP 1500 & $\begin{array}{l}\text { Smart } \\
\text { Sensors/ } \\
\text { HOBO }\end{array}$ & 1500 & $\begin{array}{l}13^{\circ} 2^{\prime} 57.577^{\prime \prime} \\
71^{\circ} 32^{\prime} 11.579 "\end{array}$ & $\begin{array}{l}\text { LMCF/LM } \\
\text { RF }\end{array}$ & $\begin{array}{l}\text { Mountain } \\
\text { slope }\end{array}$ & 170 & 29.5 & 1322.0 & 74.9 & $95^{\star 9}$ & $4956^{b}$ & $5191(5321)$ & 908 & 328 & 540 \\
\hline 9 & $\begin{array}{l}\text { Chonta- } \\
\text { chaca }\end{array}$ & manual & 887 & $\begin{array}{l}13^{\circ} 1 ' 26.091 ", \\
71^{\circ} 28^{\prime} 4.887^{\prime \prime}\end{array}$ & LTRF & $\begin{array}{l}\text { Low } \\
\text { mountains } \\
\text { near road } \\
\text { and river }\end{array}$ & -1 & 2.1 & 8027.3 & $83.6^{\wedge}$ & $\mathrm{N} / \mathrm{A}$ & $5316^{a}$ & 5260 (5392) & $\mathrm{N} / \mathrm{A}$ & $\mathrm{N} / \mathrm{A}$ & $\mathrm{N} / \mathrm{A}$ \\
\hline
\end{tabular}

Stations 2, 3, 4, 6, 7 and 8 are run by the ABERG consortium.

a data from (SENAMHI, 2012)

b data from (Rapp and Silman, 2012)

${ }^{c}$ data from (Girardin et al., 2014)

data from (Huaraca Huasco et al., 2014; ACCA, 2012)

F Data for the two San Pedro meteorological stations were merged since they were located close to one another and totalled only 13 months of data.

\$TRMM calibrated rainfall $\left(\mathrm{mm} \mathrm{yr}^{-1}\right)$ from 1998 to $2012(n=180$ months) was determined for each meteorological station as described in the text. Data in

parenthesis is rainfall corrected for wind-induced loss at $2.5 \%$ (Table S3).

UMCF $=$ Upper montane cloud forest, LMCF = Lower montane cloud forest, LMRF $=$ Lower montane rain forest, LTRF $=$ Lower tropical rainforest.

$\wedge \wedge$ Aspect and slope were determined by using SRTM DEM at $90 \mathrm{~m} \times 90 \mathrm{~m}$ resolution.

$n=$ available months of meteorological station data.

$T_{\max }=$ mean max daily temperature averaged monthly

$R H_{\min }=$ mean daily minimum relative humidity averaged monthly, ${ }^{\wedge}$ estimated $R H_{\min }$ using dry and wet bulb temperatures assuming atmospheric pressure was

$1013 \mathrm{hPa}$, and $R_{\mathrm{n}}=$ mean daily net radiation averaged monthly.

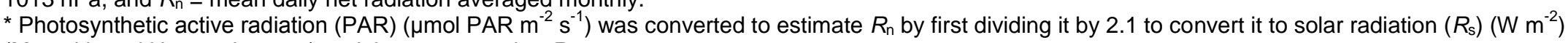

(Monteith and Unsworth, 2013) and then converted to $R_{n}$.

Solar radiation was converted to estimate net radiation $\left(R_{n}\right)$ by multiplying $R_{\mathrm{s}}$ by $0.5^{\mathrm{e}}$ (Gilmanov et al., 2007), $0.7^{\dagger}$ (Holwerda, 2005$)$ or $0.75^{\mathrm{g}}$ (Fisher et al., 2010 ;

Malhi et al., 2002) Actual evapotranspiration (AET) estimated using meteorological station data in the PT-JPL model developed by Fisher et al. (2008).

$A E T$ is composed of rainfall interception (AETi), canopy transpiration (AETC), and soil evaporation (AETs).

${ }^{\mathrm{h}}$ data from 2013 - 2014 collected by Y. Malhi and used only in the AET analysis. 
TABLE S3: Wind speed and wind-induced rainfall loss for the Kosñipata catchment

\begin{tabular}{lll}
\hline \multicolumn{2}{c}{ Wind velocity $\left(\mathrm{m} \mathrm{s}^{-1}\right)$} & Rainfall loss due to wind $(\%)^{*}$ \\
\hline Wet & $1.22 \pm 0.08$ & $2.41 \pm 0.34$ \\
Wet-dry & $1.16 \pm 0.12$ & $2.19 \pm 0.37$ \\
Dry & $1.40 \pm 0.24$ & $2.41 \pm 0.76$ \\
Dry-wet & $1.37 \pm 0.08$ & $2.98 \pm 0.34$ \\
\hline Annual & $1.32 \pm 0.17$ & $2.50 \pm 0.56$ \\
\hline \multicolumn{2}{l}{ Meteorological stations used were TR 3750, TR 2750, TR 1800, and SP 1500 (see Table S2 for descriptions). } \\
*Rainfall loss due to wind around the rain gauge was estimated based on equations 1 and 2 from (Holwerda et al., 2006). \\
\multicolumn{2}{l}{} \\
\hline
\end{tabular}


TABLE S4a: Water isotope data for rainfall collected in the Kosñipata catchment

\begin{tabular}{|c|c|c|c|c|c|c|c|c|}
\hline Season & $\begin{array}{c}\text { Date } \\
\text { (dd-mmm-yy) }\end{array}$ & $\begin{array}{c}\text { Elevation } \\
(\mathrm{m})\end{array}$ & $\begin{array}{l}\delta^{18} \mathrm{O} \\
(\% 0)\end{array}$ & $\begin{array}{c}\sigma \delta^{18} O \\
(\% 0)\end{array}$ & $\begin{array}{l}\delta \mathrm{D} \\
(\% 0) \\
\end{array}$ & $\begin{array}{l}\sigma \delta \mathrm{D} \\
(\% \circ)\end{array}$ & $\begin{array}{l}\text { Dxs } \\
(\%)\end{array}$ & $\begin{array}{c}\sigma \text { Dxs } \\
(\% 0)\end{array}$ \\
\hline Dry season & 13-Jun-11 & 1360 & -4.63 & 0.10 & -18.89 & 0.57 & 18.18 & 0.98 \\
\hline Wet season & 19-Dec-10 & 1360 & -2.46 & 0.14 & -17.70 & 0.98 & 1.95 & 1.46 \\
\hline Wet season & 22-Mar-11 & 1360 & -12.44 & 0.16 & -92.29 & 0.45 & 7.22 & 1.36 \\
\hline Wet season & 27-Dec-10 & 1360 & -15.22 & 0.24 & -111.36 & 0.45 & 10.40 & 1.98 \\
\hline Wet season & 24-Jan-11 & 1360 & -16.49 & 0.06 & -129.76 & 0.74 & 2.16 & 0.87 \\
\hline Wet season & 21-Feb-11 & 1360 & -18.58 & 0.08 & -138.96 & 0.41 & 9.66 & 0.75 \\
\hline Dry season & 06-Jul-09 & 1500 & -7.19 & 0.08 & -40.73 & 0.50 & 16.82 & 0.81 \\
\hline Dry season & 06-Jul-09 & 1500 & -7.18 & 0.08 & -40.69 & 0.50 & 16.71 & 0.81 \\
\hline Dry season & 06-Jul-09 & 1500 & -7.16 & 0.08 & -40.73 & 0.50 & 16.52 & 0.81 \\
\hline Dry season & 07-Jul-09 & 1500 & -7.39 & 0.08 & -41.90 & 0.50 & 17.25 & 0.81 \\
\hline Dry season & 07-Jul-09 & 1500 & -7.41 & 0.08 & -42.00 & 0.50 & 17.30 & 0.81 \\
\hline Dry season & 07-Jul-09 & 1500 & -7.57 & 0.08 & -42.96 & 0.50 & 17.58 & 0.81 \\
\hline Dry season & 14-Sep-09 & 1500 & -2.55 & 0.08 & 1.81 & 0.50 & 22.19 & 0.81 \\
\hline Dry season & 14-Sep-09 & 1500 & -2.08 & 0.08 & 4.46 & 0.50 & 21.08 & 0.81 \\
\hline Dry season & 14-Sep-09 & 1500 & -1.93 & 0.08 & 7.70 & 0.50 & 23.13 & 0.81 \\
\hline Dry season & 15-Sep-09 & 1500 & -1.56 & 0.08 & 3.72 & 0.50 & 16.19 & 0.81 \\
\hline Dry season & 16-Sep-09 & 1500 & -2.70 & 0.08 & 0.21 & 0.50 & 21.84 & 0.81 \\
\hline Dry season & 16-Sep-09 & 1500 & -0.94 & 0.08 & 9.36 & 0.50 & 16.85 & 0.81 \\
\hline Dry season & 05-Jul-09 & 2000 & -6.62 & 0.08 & -35.67 & 0.50 & 17.26 & 0.81 \\
\hline Dry season & 05-Jul-09 & 2000 & -6.57 & 0.08 & -35.59 & 0.50 & 16.95 & 0.81 \\
\hline Dry season & 05-Jul-09 & 2000 & -6.58 & 0.08 & -35.49 & 0.50 & 17.17 & 0.81 \\
\hline Dry season & 12-Sep-09 & 2000 & -1.61 & 0.08 & 6.26 & 0.50 & 19.17 & 0.81 \\
\hline Dry season & 12-Sep-09 & 2000 & -3.10 & 0.08 & -2.88 & 0.50 & 21.89 & 0.81 \\
\hline Dry season & 12-Sep-09 & 2000 & -1.75 & 0.08 & 6.11 & 0.50 & 20.08 & 0.81 \\
\hline Dry season & 12-Sep-09 & 2000 & -1.59 & 0.08 & 6.70 & 0.50 & 19.42 & 0.81 \\
\hline Wet season & $20-F e b-11$ & 2040 & -22.81 & 0.29 & -168.28 & 1.34 & 14.18 & 2.65 \\
\hline Wet season & 20-Feb-11 & 2050 & -22.50 & 0.14 & -170.76 & 0.87 & 9.25 & 1.39 \\
\hline Wet season & 20-Feb-11 & 2130 & -14.71 & 0.16 & -105.35 & 0.77 & 12.35 & 1.51 \\
\hline Dry season & 28-Jun-10 & 2290 & -3.88 & 0.06 & -16.21 & 0.91 & 14.86 & 1.03 \\
\hline Dry season & 28-Jun-10 & 2290 & -6.73 & 0.20 & -36.95 & 0.82 & 16.86 & 1.80 \\
\hline Wet season & 22-Mar-10 & 2290 & -8.32 & 0.27 & -56.74 & 0.52 & 9.80 & 2.19 \\
\hline Wet season & 19-Feb-11 & 2290 & -10.40 & 0.07 & -72.11 & 0.33 & 11.08 & 0.64 \\
\hline Wet season & 27-Dec-10 & 2290 & -17.72 & 0.08 & -136.09 & 0.60 & 5.70 & 0.89 \\
\hline Wet season & 19-Feb-11 & 2300 & -14.52 & 0.09 & -100.38 & 0.70 & 15.77 & 0.99 \\
\hline Wet season & 19-Feb-11 & 2400 & -12.46 & 0.17 & -87.71 & 0.32 & 11.93 & 1.37 \\
\hline Dry season & 03-Jul-07 & 2500 & -5.69 & 0.08 & -28.75 & 0.50 & 16.76 & 0.81 \\
\hline Dry season & 03-Jul-07 & 2500 & -5.50 & 0.08 & -27.76 & 0.50 & 16.24 & 0.81 \\
\hline Dry season & 03-Jul-07 & 2500 & -5.82 & 0.08 & -29.33 & 0.50 & 17.22 & 0.81 \\
\hline Dry season & 03-Jul-07 & 2500 & -7.97 & 0.08 & -45.49 & 0.50 & 18.25 & 0.81 \\
\hline
\end{tabular}




\begin{tabular}{lllllllll} 
Dry season & 03-Jul-07 & 2500 & -7.96 & 0.08 & -45.77 & 0.50 & 17.90 & 0.81 \\
Dry season & 03-Jul-07 & 2500 & -7.95 & 0.08 & -46.08 & 0.50 & 17.51 & 0.81 \\
Dry season & 08-Sep-09 & 2500 & -0.85 & 0.08 & 14.33 & 0.50 & 21.16 & 0.81 \\
Dry season & 08-Sep-09 & 2500 & -0.89 & 0.08 & 14.32 & 0.50 & 21.48 & 0.81 \\
Dry season & 08-Sep-09 & 2500 & -0.75 & 0.08 & 15.40 & 0.50 & 21.41 & 0.81 \\
Dry season & 08-Sep-09 & 2500 & -0.85 & 0.08 & 14.12 & 0.50 & 20.93 & 0.81 \\
Dry season & 08-Sep-09 & 2500 & -0.78 & 0.08 & 14.90 & 0.50 & 21.17 & 0.81 \\
Dry season & 08-Sep-09 & 2500 & -0.96 & 0.08 & 14.23 & 0.50 & 21.93 & 0.81 \\
Dry season & 10-Sep-09 & 2500 & -2.19 & 0.08 & 3.70 & 0.50 & 21.18 & 0.81 \\
Dry season & 10-Sep-09 & 2500 & -4.25 & 0.08 & -12.50 & 0.50 & 21.47 & 0.81 \\
Dry season & 10-Sep-09 & 2500 & -3.89 & 0.08 & -10.05 & 0.50 & 21.08 & 0.81 \\
Dry season & 10-Sep-09 & 2500 & -2.32 & 0.08 & 2.95 & 0.50 & 21.47 & 0.81 \\
Dry season & 10-Sep-09 & 2500 & -4.45 & 0.08 & -14.42 & 0.50 & 21.19 & 0.81 \\
Dry season & 10-Sep-09 & 2500 & -3.78 & 0.08 & -9.74 & 0.50 & 20.54 & 0.81 \\
Dry season & 01-Jul-09 & 3000 & -7.00 & 0.08 & -41.47 & 0.50 & 14.51 & 0.81 \\
Dry season & 01-Jul-09 & 3000 & -6.92 & 0.08 & -40.57 & 0.50 & 14.83 & 0.81 \\
Dry season & 01-Jul-09 & 3000 & -6.83 & 0.08 & -40.99 & 0.50 & 13.66 & 0.81 \\
Dry season & 01-Jul-09 & 3000 & -7.15 & 0.08 & -42.20 & 0.50 & 15.03 & 0.81 \\
Dry season & 01-Jul-09 & 3000 & -7.11 & 0.08 & -41.47 & 0.50 & 15.42 & 0.81 \\
Dry season & 01-Jul-09 & 3000 & -7.38 & 0.08 & -44.05 & 0.50 & 14.97 & 0.81 \\
Dry season & 09-Sep-09 & 3000 & -1.76 & 0.08 & 8.20 & 0.50 & 22.24 & 0.81 \\
Dry season & 09-Sep-09 & 3000 & -1.68 & 0.08 & 9.05 & 0.50 & 22.47 & 0.81 \\
Dry season & 09-Sep-09 & 3000 & -2.17 & 0.08 & 5.89 & 0.50 & 23.21 & 0.81 \\
Dry season & 09-Sep-09 & 3000 & -2.15 & 0.08 & 6.22 & 0.50 & 23.43 & 0.81 \\
Dry season & 09-Sep-09 & 3000 & -1.29 & 0.08 & 9.82 & 0.50 & 20.10 & 0.81 \\
\hline & & & & & & & &
\end{tabular}

TABLE S4b: Water isotope data for cloud water collected in the Kosñipata catchment

\begin{tabular}{lcccccccc}
\hline & $\begin{array}{c}\text { Date } \\
(\mathrm{dd}-\mathrm{mmm}-\mathrm{yy})\end{array}$ & $\begin{array}{c}\text { Elevation } \\
(\mathrm{m})\end{array}$ & $\begin{array}{c}\delta^{18} \mathrm{O} \\
(\%)\end{array}$ & $\begin{array}{c}\sigma \delta^{18} \mathrm{O}^{*} \\
(\% \circ)\end{array}$ & $\begin{array}{c}\delta \mathrm{D} \\
(\%)\end{array}$ & $\begin{array}{c}\sigma \delta \mathrm{D}^{*} \\
(\%)\end{array}$ & $\begin{array}{c}\text { Dxs } \\
(\%)\end{array}$ & $\begin{array}{c}\sigma \text { Dxs } \\
(\%)\end{array}$ \\
\hline Cloud water & 14-Sep-09 & 1500 & -1.40 & 0.08 & 15.34 & 0.50 & 26.57 & 0.81 \\
Cloud water & 14-Sep-09 & 1500 & -0.47 & 0.08 & 19.81 & 0.50 & 23.60 & 0.81 \\
Cloud water & 14-Sep-09 & 1500 & -1.48 & 0.08 & 14.71 & 0.50 & 26.56 & 0.81 \\
Cloud water & 14-Sep-09 & 1500 & -1.86 & 0.08 & 14.35 & 0.50 & 29.21 & 0.81 \\
Cloud water & 14-Sep-09 & 1500 & -5.09 & 0.08 & -0.04 & 0.50 & 40.65 & 0.81 \\
Cloud water & 14-Sep-09 & 1500 & -2.71 & 0.08 & 11.87 & 0.50 & 33.51 & 0.81 \\
Cloud water & 12-Sep-09 & 2000 & -3.81 & 0.08 & -1.71 & 0.50 & 28.76 & 0.81 \\
Cloud water & 12-Sep-09 & 2000 & -2.40 & 0.08 & 3.30 & 0.50 & 22.48 & 0.81 \\
Cloud water & 12-Sep-09 & 2000 & -7.32 & 0.08 & -18.41 & 0.50 & 40.15 & 0.81 \\
Cloud water & 12-Sep-09 & 2000 & -5.77 & 0.08 & -11.47 & 0.50 & 34.69 & 0.81 \\
Cloud water & 12-Sep-09 & 2000 & -6.09 & 0.08 & -12.16 & 0.50 & 36.53 & 0.81 \\
Cloud water & 03-Jul-07 & 2500 & -8.29 & 0.08 & -41.50 & 0.50 & 24.80 & 0.81 \\
Cloud water & 03-Jul-07 & 2500 & -16.04 & 0.08 & -68.33 & 0.50 & 60.00 & 0.81 \\
Cloud water & 03-Jul-07 & 2500 & -16.94 & 0.08 & -68.80 & 0.50 & 66.75 & 0.81
\end{tabular}




\begin{tabular}{|c|c|c|c|c|c|c|c|c|}
\hline Cloud water & 03-Jul-07 & 2500 & -12.28 & 0.08 & -42.91 & 0.50 & 55.36 & 0.81 \\
\hline Cloud water & 03-Jul-07 & 2500 & -11.65 & 0.08 & -52.50 & 0.50 & 40.68 & 0.81 \\
\hline Cloud water & 03-Jul-07 & 2500 & -13.10 & 0.08 & -64.09 & 0.50 & 40.74 & 0.81 \\
\hline Cloud water & 10-Sep-09 & 2500 & -4.99 & 0.08 & -9.89 & 0.50 & 30.04 & 0.81 \\
\hline Cloud water & 10-Sep-09 & 2500 & -3.31 & 0.08 & -3.67 & 0.50 & 22.83 & 0.81 \\
\hline Cloud water & 10-Sep-09 & 2500 & -3.99 & 0.08 & -10.70 & 0.50 & 21.21 & 0.81 \\
\hline Cloud water & 10-Sep-09 & 2500 & -7.55 & 0.08 & -23.47 & 0.50 & 36.93 & 0.81 \\
\hline Cloud water & 10-Sep-09 & 2500 & -5.36 & 0.08 & -7.96 & 0.50 & 34.92 & 0.81 \\
\hline Cloud water & 10-Sep-09 & 2500 & -7.14 & 0.08 & -16.74 & 0.50 & 40.40 & 0.81 \\
\hline Cloud water & 01-Jul-09 & 3000 & -12.38 & 0.08 & -66.54 & 0.50 & 32.50 & 0.81 \\
\hline Cloud water & 01-Jul-09 & 3000 & -18.29 & 0.08 & -85.17 & 0.50 & 61.14 & 0.81 \\
\hline Cloud water & 01-Jul-09 & 3000 & -16.31 & 0.08 & -101.23 & 0.50 & 29.27 & 0.81 \\
\hline Cloud water & 01-Jul-09 & 3000 & -18.31 & 0.08 & -86.05 & 0.50 & 60.40 & 0.81 \\
\hline Cloud water & 01-Jul-09 & 3000 & -12.46 & 0.08 & -56.25 & 0.50 & 43.45 & 0.81 \\
\hline Cloud water & 01-Jul-09 & 3000 & -16.89 & 0.08 & -75.90 & 0.50 & 59.19 & 0.81 \\
\hline Cloud water & 09-Sep-09 & 3000 & -6.02 & 0.08 & -10.35 & 0.50 & 37.85 & 0.81 \\
\hline Cloud water & 09-Sep-09 & 3000 & -6.00 & 0.08 & -11.65 & 0.50 & 36.33 & 0.81 \\
\hline Cloud water & 09-Sep-09 & 3000 & -9.00 & 0.08 & -29.96 & 0.50 & 42.03 & 0.81 \\
\hline Cloud water & 09-Sep-09 & 3000 & -8.23 & 0.08 & -32.36 & 0.50 & 33.50 & 0.81 \\
\hline Cloud water & 09-Sep-09 & 3000 & -6.13 & 0.08 & -21.52 & 0.50 & 27.54 & 0.81 \\
\hline Cloud water & 09-Sep-09 & 3000 & -5.34 & 0.08 & -19.10 & 0.50 & 23.64 & 0.81 \\
\hline Cloud water & 30-Jun-09 & 3600 & -9.89 & 0.08 & -48.36 & 0.50 & 30.76 & 0.81 \\
\hline Cloud water & 30-Jun-09 & 3600 & -11.76 & 0.08 & -54.14 & 0.50 & 39.94 & 0.81 \\
\hline Cloud water & 30-Jun-09 & 3600 & -13.24 & 0.08 & -62.96 & 0.50 & 42.99 & 0.81 \\
\hline Cloud water & 30-Jun-09 & 3600 & -13.53 & 0.08 & -62.00 & 0.50 & 46.21 & 0.81 \\
\hline Cloud water & 30-Jun-09 & 3600 & -14.47 & 0.08 & -68.30 & 0.50 & 47.43 & 0.81 \\
\hline Cloud water & 30-Jun-09 & 3600 & -14.04 & 0.08 & -64.77 & 0.50 & 47.57 & 0.81 \\
\hline Cloud water & 07-Sep-09 & 3600 & -3.49 & 0.08 & 8.30 & 0.50 & 36.23 & 0.81 \\
\hline Cloud water & 07-Sep-09 & 3600 & -4.96 & 0.08 & 6.66 & 0.50 & 46.34 & 0.81 \\
\hline Cloud water & 07-Sep-09 & 3600 & -8.70 & 0.08 & -12.75 & 0.50 & 56.83 & 0.81 \\
\hline Cloud water & 07-Sep-09 & 3600 & -4.16 & 0.08 & 13.84 & 0.50 & 47.08 & 0.81 \\
\hline Cloud water & 07-Sep-09 & 3600 & -8.99 & 0.08 & -14.35 & 0.50 & 57.57 & 0.81 \\
\hline Cloud water & 07-Sep-09 & 3600 & -11.45 & 0.08 & -61.24 & 0.50 & 30.34 & 0.81 \\
\hline
\end{tabular}

${ }^{*}$ Characteristic analytical uncertainties reported by Horwath (2011). 
TABLE S5: Catchment-wide annual rainfall estimates $\left(\mathrm{mm} \mathrm{yr}^{-1}\right)$

\begin{tabular}{cccc}
\hline Rank & Year & $\begin{array}{c}\text { Kosñipata catchment - } \\
\text { San Pedro }\end{array}$ & $\begin{array}{c}\text { Kosñipata catchment - } \\
\text { Wayqecha sub-basin }\end{array}$ \\
\hline 1 & 2001 & 3265 & 2654 \\
2 & 2010 & 3240 & 2631 \\
3 & 2011 & 3217 & 2611 \\
4 & 2002 & 3155 & 2552 \\
5 & 2003 & 2981 & 2390 \\
6 & 2009 & 2937 & 2351 \\
7 & 2006 & 2845 & 2265 \\
8 & 2012 & 2833 & 2254 \\
9 & 2008 & 2817 & 2239 \\
10 & 1999 & 2773 & 2199 \\
11 & 2007 & 2751 & 2179 \\
12 & 1998 & 2655 & 2084 \\
13 & 2000 & 2650 & 2084 \\
14 & 2004 & 2645 & 2080 \\
15 & 2005 & 2759 & 1908 \\
Mean & $1998-2012$ & $2881 \pm 124$ & $2299 \pm 115$ \\
\hline
\end{tabular}

Uncertainties are $2 \times$ standard error of annual totals.

Rainfall values include wind-induced rainfall loss correction of $2.5 \%$.

436

437

438 
TABLE S6: Water isotope data of stream water collected from the Kosñipata River at the San Pedro gauging station

\begin{tabular}{|c|c|c|c|c|c|c|}
\hline $\begin{array}{l}\text { Date and hour } \\
\text { (dd-mmm-yy hr) }\end{array}$ & $\delta^{18} \mathrm{O}(\%)$ & $\begin{array}{c}\sigma \delta^{18} \mathrm{O} \\
(\% \circ)\end{array}$ & $\begin{array}{l}\delta D \\
(\%)\end{array}$ & $\begin{array}{c}\sigma \delta D \\
(\%)\end{array}$ & Dxs & $\sigma$ Dxs \\
\hline$\overline{01-N o v-09}$ & -11.62 & 0.14 & -77.33 & 0.65 & 15.64 & 1.32 \\
\hline 07-Nov-09 & -10.75 & 0.15 & -67.95 & 0.42 & 18.03 & 1.29 \\
\hline 15-Nov-09 & -11.47 & 0.14 & -74.89 & 0.32 & 16.89 & 1.20 \\
\hline 30-Nov-09 & -12.10 & 0.14 & -80.46 & 0.25 & 16.34 & 1.16 \\
\hline 30-Jan-10 00 & -13.44 & 0.15 & -91.94 & 0.19 & 15.61 & 1.20 \\
\hline 04-Feb-10 03 & -12.39 & 0.14 & -84.13 & 0.21 & 14.96 & 1.15 \\
\hline 04-Feb-10 09 & -12.56 & 0.14 & -85.54 & 0.19 & 14.97 & 1.15 \\
\hline 04-Feb-10 15 & -12.21 & 0.14 & -83.56 & 0.11 & 14.10 & 1.14 \\
\hline 04-Feb-10 21 & -12.38 & 0.14 & -84.32 & 0.03 & 14.72 & 1.13 \\
\hline 05-Feb-10 09 & -12.57 & 0.14 & -85.21 & 0.29 & 15.35 & 1.17 \\
\hline 05-Feb-10 15 & -12.45 & 0.14 & -84.67 & 0.42 & 14.90 & 1.21 \\
\hline 05-Feb-10 21 & -12.35 & 0.14 & -84.08 & 0.28 & 14.75 & 1.17 \\
\hline 06-Feb-10 09 & -12.47 & 0.14 & -85.04 & 0.29 & 14.72 & 1.17 \\
\hline 06-Feb-10 15 & -12.48 & 0.14 & -85.09 & 0.31 & 14.75 & 1.18 \\
\hline 07-Feb-10 & -12.55 & 0.14 & -86.01 & 0.16 & 14.41 & 1.15 \\
\hline 07-Feb-10 03 & -12.44 & 0.14 & -84.94 & 0.48 & 14.56 & 1.23 \\
\hline 07-Feb-10 09 & -12.58 & 0.14 & -84.71 & 0.51 & 15.91 & 1.25 \\
\hline 07-Feb-10 15 & -12.55 & 0.14 & -84.50 & 0.33 & 15.90 & 1.18 \\
\hline 07-Feb-10 21 & -12.52 & 0.14 & -85.04 & 0.28 & 15.12 & 1.17 \\
\hline 08-Feb-10 03 & -12.44 & 0.14 & -85.22 & 0.29 & 14.29 & 1.17 \\
\hline 08-Feb-10 09 & -12.59 & 0.14 & -84.27 & 0.07 & 16.48 & 1.14 \\
\hline 08-Feb-10 15 & -12.63 & 0.14 & -84.58 & 0.09 & 16.47 & 1.14 \\
\hline 08-Feb-10 21 & -12.60 & 0.14 & -84.10 & 0.39 & 16.71 & 1.20 \\
\hline 09-Feb-10 03 & -12.60 & 0.14 & -85.03 & 0.22 & 15.79 & 1.16 \\
\hline 09-Feb-10 09 & -12.69 & 0.14 & -85.19 & 0.25 & 16.33 & 1.17 \\
\hline 09-Feb-10 15 & -12.69 & 0.14 & -85.71 & 0.13 & 15.80 & 1.15 \\
\hline 10-Feb-10 03 & -12.68 & 0.14 & -85.25 & 0.43 & 16.22 & 1.22 \\
\hline 11-Feb-10 09 & -12.63 & 0.14 & -85.00 & 0.46 & 16.08 & 1.23 \\
\hline 11-Feb-10 21 & -11.80 & 0.14 & -78.70 & 0.11 & 15.72 & 1.15 \\
\hline 12-Feb-10 05 & -11.93 & 0.14 & -81.34 & 0.39 & 14.12 & 1.20 \\
\hline 12-Feb-10 09 & -12.18 & 0.14 & -82.38 & 0.22 & 15.10 & 1.15 \\
\hline 12-Feb-10 14 & -12.17 & 0.14 & -81.88 & 0.54 & 15.46 & 1.26 \\
\hline 22-Feb-10 & -12.53 & 0.14 & -85.18 & 0.68 & 15.03 & 1.32 \\
\hline 22-Mar-10 & -12.51 & 0.14 & -85.15 & 0.83 & 14.90 & 1.41 \\
\hline 29-Mar-10 & -12.53 & 0.14 & -85.63 & 0.07 & 14.64 & 1.14 \\
\hline 05-Apr-10 & -12.09 & 0.14 & -80.72 & 0.53 & 16.03 & 1.25 \\
\hline 25-Apr-10 & -12.46 & 0.14 & -83.80 & 0.50 & 15.85 & 1.24 \\
\hline 16-May-10 & -12.38 & 0.14 & -83.30 & 0.24 & 15.72 & 1.16 \\
\hline 26-May-10 & -12.14 & 0.14 & -81.43 & 1.18 & 15.65 & 1.64 \\
\hline 31-May-10 & -11.39 & 0.15 & -74.59 & 0.30 & 16.56 & 1.20 \\
\hline 14-Jun-10 & -12.20 & 0.14 & -81.47 & 0.13 & 16.10 & 1.14 \\
\hline 12-Jul-10 & -11.27 & 0.15 & -74.51 & 0.31 & 15.63 & 1.21 \\
\hline 19-Jul-10 & -11.89 & 0.14 & -79.62 & 0.45 & 15.53 & 1.22 \\
\hline
\end{tabular}

Cont. next page... 
TABLE S6, cont.: Water isotope data of stream water collected from the Kosñipata River at San Pedro gauging station

\begin{tabular}{|c|c|c|c|c|c|c|}
\hline $\begin{array}{l}\text { Date and hour } \\
\text { (dd-mmm-yy hr) }\end{array}$ & $\delta^{18} \mathrm{O}(\%)$ & $\begin{array}{c}\sigma \delta^{18} \mathrm{O} \\
(\%)\end{array}$ & $\begin{array}{l}\mathrm{DD} \\
(\%)\end{array}$ & $\begin{array}{c}\sigma \delta D \\
(\% \circ)\end{array}$ & Dxs & $\sigma$ Dxs \\
\hline 11-Aug-10 & -11.68 & 0.14 & -77.67 & 0.37 & 15.76 & 1.20 \\
\hline 18-Aug-10 & -11.64 & 0.17 & -79.54 & 0.98 & 13.55 & 1.67 \\
\hline 23-Aug-10 & -11.88 & 0.14 & -80.02 & 1.31 & 15.04 & 1.74 \\
\hline 02-Sep-10 & -10.37 & 0.16 & -64.99 & 1.61 & 18.01 & 2.04 \\
\hline 04-Sep-10 & -11.05 & 0.15 & -70.85 & 1.49 & 17.55 & 1.90 \\
\hline 13-Sep-10 & -11.36 & 0.23 & -76.20 & 1.06 & 14.70 & 2.15 \\
\hline 15-Oct-10 & -8.94 & 0.09 & -58.85 & 0.17 & 12.64 & 0.71 \\
\hline $15-$ Nov-10 & -10.72 & 0.21 & -71.86 & 0.68 & 13.90 & 1.83 \\
\hline 19-Nov-10 & -10.64 & 0.24 & -68.22 & 0.57 & 16.94 & 1.97 \\
\hline 22-Nov-10 & -10.63 & 0.46 & -64.93 & 0.47 & 20.09 & 3.74 \\
\hline 06-Dec-10 & -11.38 & 0.15 & -74.37 & 0.46 & 16.68 & 1.25 \\
\hline 13-Dec-10 & -12.26 & 0.18 & -76.37 & 0.31 & 21.68 & 1.45 \\
\hline 20-Dec-10 & -11.49 & 0.18 & -76.90 & 0.60 & 15.03 & 1.57 \\
\hline 27-Dec-10 & -12.54 & 0.11 & -86.25 & 0.28 & 14.05 & 0.90 \\
\hline 03-Jan-11 & -11.90 & 0.14 & -80.14 & 0.36 & 15.05 & 1.19 \\
\hline 24-Jan-11 & -11.63 & 0.19 & -79.70 & 0.70 & 13.38 & 1.69 \\
\hline 08-Mar-11 & -13.79 & 0.15 & -94.88 & 0.23 & 15.43 & 1.24 \\
\hline 05-May-11 & -13.04 & 0.14 & -88.81 & 0.74 & 15.49 & 1.37 \\
\hline 18-Jul-11 & -12.09 & 0.18 & -80.61 & 0.75 & 16.08 & 1.66 \\
\hline
\end{tabular}

Mean isotope values and $\sigma$ (standard deviation) were from 3 replicate sample injections (see description of methods in Supplementary Text)

\# hour not reported when only one sample collected on a given date 
TABLE S7: Results of Monte Carlo analysis of mixing fractions for water isotope samples from the Kosñipata River at the San Pedro gauging station

\begin{tabular}{|c|c|c|c|c|c|c|c|c|c|c|c|c|c|}
\hline \multirow{2}{*}{$\begin{array}{l}\text { Date and hour } \\
\text { (dd-mmm-yy hr) }\end{array}$} & \multicolumn{4}{|c|}{ Wet Rain } & \multicolumn{4}{|c|}{ Dry Rain } & \multicolumn{4}{|c|}{ Cloud Water } & \multirow{2}{*}{$\begin{array}{c}\text { \# of real } \\
\text { simulations }\end{array}$} \\
\hline & Mean & $5 \%$ & $50 \%$ & $95 \%$ & Mean & $5 \%$ & $50 \%$ & $95 \%$ & Mean & $5 \%$ & $50 \%$ & $95 \%$ & \\
\hline 01-Nov-09 & 0.56 & 0.39 & 0.54 & 0.77 & 0.29 & 0.04 & 0.30 & 0.54 & 0.15 & 0.020 & 0.14 & 0.33 & $6.27 E+06$ \\
\hline 07-Nov-09 & 0.49 & 0.34 & 0.48 & 0.66 & 0.20 & 0.02 & 0.19 & 0.41 & 0.31 & 0.151 & 0.30 & 0.52 & $4.70 \mathrm{E}+06$ \\
\hline 15-Nov-09 & 0.67 & 0.50 & 0.66 & 0.86 & 0.24 & 0.03 & 0.24 & 0.45 & 0.10 & 0.008 & 0.09 & 0.24 & $4.05 E+06$ \\
\hline 30-Nov-09 & 0.60 & 0.42 & 0.59 & 0.83 & 0.28 & 0.03 & 0.28 & 0.52 & 0.12 & 0.011 & 0.10 & 0.28 & $4.98 \mathrm{E}+06$ \\
\hline 30-Jan-10 00 & 0.62 & 0.45 & 0.61 & 0.83 & 0.27 & 0.03 & 0.27 & 0.50 & 0.12 & 0.011 & 0.10 & 0.27 & $5.00 \mathrm{E}+06$ \\
\hline 04-Feb-10 03 & 0.66 & 0.52 & 0.65 & 0.83 & 0.21 & 0.02 & 0.21 & 0.40 & 0.13 & 0.017 & 0.12 & 0.29 & $4.34 \mathrm{E}+06$ \\
\hline 04-Feb-10 09 & 0.65 & 0.46 & 0.64 & 0.87 & 0.25 & 0.03 & 0.25 & 0.49 & 0.09 & 0.007 & 0.08 & 0.24 & $3.48 \mathrm{E}+06$ \\
\hline 04-Feb-10 15 & 0.65 & 0.48 & 0.64 & 0.86 & 0.25 & 0.03 & 0.25 & 0.47 & 0.10 & 0.008 & 0.09 & 0.24 & $4.12 \mathrm{E}+06$ \\
\hline 04-Feb-10 21 & 0.64 & 0.48 & 0.63 & 0.85 & 0.25 & 0.03 & 0.25 & 0.46 & 0.11 & 0.010 & 0.10 & 0.26 & $4.57 \mathrm{E}+06$ \\
\hline 05-Feb-10 09 & 0.64 & 0.47 & 0.63 & 0.84 & 0.25 & 0.03 & 0.25 & 0.47 & 0.12 & 0.011 & 0.10 & 0.27 & $4.74 \mathrm{E}+06$ \\
\hline 05-Feb-10 15 & 0.64 & 0.48 & 0.63 & 0.84 & 0.24 & 0.03 & 0.24 & 0.45 & 0.12 & 0.012 & 0.10 & 0.27 & $4.65 E+06$ \\
\hline 05-Feb-10 21 & 0.64 & 0.48 & 0.63 & 0.84 & 0.24 & 0.03 & 0.25 & 0.46 & 0.12 & 0.011 & 0.10 & 0.27 & $4.64 \mathrm{E}+06$ \\
\hline 06-Feb-10 09 & 0.64 & 0.47 & 0.63 & 0.84 & 0.25 & 0.03 & 0.25 & 0.47 & 0.11 & 0.011 & 0.10 & 0.26 & $4.60 \mathrm{E}+06$ \\
\hline 06-Feb-10 15 & 0.63 & 0.48 & 0.62 & 0.83 & 0.24 & 0.03 & 0.24 & 0.46 & 0.12 & 0.014 & 0.11 & 0.28 & $4.87 E+06$ \\
\hline 07-Feb-10 & 0.65 & 0.48 & 0.63 & 0.85 & 0.24 & 0.03 & 0.24 & 0.46 & 0.11 & 0.011 & 0.10 & 0.26 & $4.54 \mathrm{E}+06$ \\
\hline 07-Feb-10 03 & 0.65 & 0.48 & 0.63 & 0.85 & 0.24 & 0.03 & 0.24 & 0.46 & 0.11 & 0.011 & 0.10 & 0.26 & $4.52 E+06$ \\
\hline 07-Feb-10 09 & 0.62 & 0.47 & 0.61 & 0.81 & 0.24 & 0.03 & 0.25 & 0.46 & 0.14 & 0.017 & 0.12 & 0.30 & $5.13 E+06$ \\
\hline 07-Feb-10 15 & 0.64 & 0.48 & 0.63 & 0.84 & 0.24 & 0.03 & 0.25 & 0.46 & 0.12 & 0.012 & 0.11 & 0.28 & $4.76 \mathrm{E}+06$ \\
\hline 07-Feb-10 21 & 0.65 & 0.48 & 0.64 & 0.85 & 0.24 & 0.03 & 0.24 & 0.46 & 0.11 & 0.010 & 0.10 & 0.26 & $4.40 E+06$ \\
\hline 08-Feb-10 03 & 0.62 & 0.47 & 0.61 & 0.82 & 0.24 & 0.03 & 0.24 & 0.46 & 0.14 & 0.017 & 0.13 & 0.30 & $5.09 \mathrm{E}+06$ \\
\hline 08-Feb-10 09 & 0.66 & 0.49 & 0.65 & 0.86 & 0.24 & 0.03 & 0.24 & 0.45 & 0.11 & 0.010 & 0.09 & 0.25 & $4.27 \mathrm{E}+06$ \\
\hline 08-Feb-10 15 & 0.61 & 0.46 & 0.60 & 0.80 & 0.24 & 0.03 & 0.24 & 0.45 & 0.15 & 0.023 & 0.14 & 0.32 & $5.25 E+06$ \\
\hline 08-Feb-10 21 & 0.60 & 0.46 & 0.59 & 0.79 & 0.24 & 0.03 & 0.24 & 0.46 & 0.16 & 0.025 & 0.15 & 0.33 & $5.29 \mathrm{E}+06$ \\
\hline 09-Feb-10 03 & 0.66 & 0.49 & 0.64 & 0.86 & 0.24 & 0.03 & 0.24 & 0.46 & 0.10 & 0.009 & 0.09 & 0.25 & $4.21 E+06$ \\
\hline 09-Feb-10 09 & 0.61 & 0.46 & 0.60 & 0.80 & 0.24 & 0.03 & 0.24 & 0.46 & 0.15 & 0.023 & 0.14 & 0.32 & $5.28 \mathrm{E}+06$ \\
\hline
\end{tabular}




\begin{tabular}{|c|c|c|c|c|c|c|c|c|c|c|c|c|c|}
\hline 09-Feb-10 15 & 0.62 & 0.47 & 0.61 & 0.82 & 0.24 & 0.03 & 0.24 & 0.46 & 0.13 & 0.017 & 0.12 & 0.30 & $5.06 \mathrm{E}+06$ \\
\hline 10-Feb-10 03 & 0.62 & 0.47 & 0.60 & 0.80 & 0.24 & 0.03 & 0.24 & 0.45 & 0.15 & 0.022 & 0.14 & 0.32 & $5.16 \mathrm{E}+06$ \\
\hline 11-Feb-10 09 & 0.63 & 0.47 & 0.61 & 0.82 & 0.24 & 0.03 & 0.24 & 0.45 & 0.13 & 0.017 & 0.12 & 0.30 & $5.01 E+06$ \\
\hline 11-Feb-10 21 & 0.62 & 0.47 & 0.61 & 0.81 & 0.24 & 0.03 & 0.24 & 0.45 & 0.15 & 0.020 & 0.13 & 0.31 & $5.12 \mathrm{E}+06$ \\
\hline 12-Feb-10 05 & 0.60 & 0.43 & 0.58 & 0.81 & 0.27 & 0.03 & 0.28 & 0.51 & 0.13 & 0.014 & 0.11 & 0.29 & $5.53 E+06$ \\
\hline 12-Feb-10 09 & 0.62 & 0.47 & 0.61 & 0.81 & 0.24 & 0.03 & 0.24 & 0.45 & 0.14 & 0.019 & 0.13 & 0.31 & $5.11 \mathrm{E}+06$ \\
\hline 12-Feb-10 14 & 0.62 & 0.45 & 0.60 & 0.82 & 0.26 & 0.03 & 0.26 & 0.48 & 0.13 & 0.013 & 0.11 & 0.29 & $5.12 \mathrm{E}+06$ \\
\hline 22-Feb-10 & 0.64 & 0.46 & 0.64 & 0.86 & 0.26 & 0.03 & 0.26 & 0.48 & 0.10 & 0.008 & 0.09 & 0.25 & $4.19 E+06$ \\
\hline 22-Mar-10 & 0.63 & 0.46 & 0.61 & 0.83 & 0.26 & 0.03 & 0.26 & 0.48 & 0.12 & 0.012 & 0.10 & 0.27 & $4.92 E+06$ \\
\hline 29-Mar-10 & 0.64 & 0.48 & 0.63 & 0.84 & 0.24 & 0.03 & 0.24 & 0.46 & 0.12 & 0.012 & 0.11 & 0.28 & $4.64 \mathrm{E}+06$ \\
\hline 05-Apr-10 & 0.67 & 0.54 & 0.66 & 0.85 & 0.19 & 0.02 & 0.19 & 0.38 & 0.13 & 0.016 & 0.12 & 0.29 & $4.01 E+06$ \\
\hline 25-Apr-10 & 0.64 & 0.48 & 0.63 & 0.84 & 0.24 & 0.03 & 0.24 & 0.46 & 0.12 & 0.012 & 0.10 & 0.27 & $4.55 \mathrm{E}+06$ \\
\hline 16-May-10 & 0.65 & 0.49 & 0.64 & 0.85 & 0.24 & 0.03 & 0.24 & 0.45 & 0.11 & 0.010 & 0.10 & 0.26 & $4.45 \mathrm{E}+06$ \\
\hline 26-May-10 & 0.60 & 0.44 & 0.59 & 0.80 & 0.26 & 0.03 & 0.27 & 0.49 & 0.14 & 0.017 & 0.12 & 0.31 & $5.47 \mathrm{E}+06$ \\
\hline 31-May-10 & 0.62 & 0.46 & 0.61 & 0.81 & 0.25 & 0.03 & 0.25 & 0.46 & 0.14 & 0.016 & 0.12 & 0.30 & $5.15 \mathrm{E}+06$ \\
\hline 14-Jun-10 & 0.65 & 0.50 & 0.63 & 0.83 & 0.22 & 0.03 & 0.22 & 0.43 & 0.13 & 0.015 & 0.12 & 0.29 & $4.54 \mathrm{E}+06$ \\
\hline 12-Jul-10 & 0.62 & 0.46 & 0.61 & 0.82 & 0.25 & 0.03 & 0.25 & 0.47 & 0.13 & 0.015 & 0.12 & 0.30 & $5.18 \mathrm{E}+06$ \\
\hline 19-Jul-10 & 0.61 & 0.44 & 0.60 & 0.82 & 0.26 & 0.03 & 0.26 & 0.48 & 0.13 & 0.014 & 0.12 & 0.31 & $5.08 \mathrm{E}+06$ \\
\hline 11-Aug-10 & 0.56 & 0.39 & 0.55 & 0.78 & 0.29 & 0.04 & 0.30 & 0.53 & 0.15 & 0.019 & 0.13 & 0.33 & $6.23 \mathrm{E}+06$ \\
\hline 18-Aug-10 & 0.60 & 0.44 & 0.59 & 0.80 & 0.26 & 0.03 & 0.26 & 0.48 & 0.14 & 0.018 & 0.13 & 0.31 & $5.47 \mathrm{E}+06$ \\
\hline 23-Aug-10 & 0.58 & 0.40 & 0.57 & 0.81 & 0.29 & 0.04 & 0.30 & 0.54 & 0.12 & 0.013 & 0.11 & 0.29 & $5.71 E+06$ \\
\hline 02-Sep-10 & 0.61 & 0.44 & 0.59 & 0.82 & 0.27 & 0.03 & 0.27 & 0.50 & 0.13 & 0.013 & 0.11 & 0.29 & $5.33 E+06$ \\
\hline 04-Sep-10 & 0.60 & 0.43 & 0.59 & 0.80 & 0.26 & 0.03 & 0.26 & 0.49 & 0.14 & 0.017 & 0.13 & 0.32 & $5.30 E+06$ \\
\hline 13-Sep-10 & 0.59 & 0.42 & 0.58 & 0.81 & 0.28 & 0.03 & 0.28 & 0.51 & 0.13 & 0.014 & 0.11 & 0.30 & $5.60 \mathrm{E}+06$ \\
\hline 15-Oct-10 & 0.62 & 0.44 & 0.60 & 0.83 & 0.26 & 0.03 & 0.27 & 0.49 & 0.12 & 0.012 & 0.11 & 0.29 & $4.78 \mathrm{E}+06$ \\
\hline $15-N o v-10$ & 0.65 & 0.46 & 0.64 & 0.86 & 0.26 & 0.03 & 0.26 & 0.49 & 0.10 & 0.007 & 0.08 & 0.24 & $3.63 E+06$ \\
\hline 19-Nov-10 & 0.49 & 0.30 & 0.47 & 0.72 & 0.33 & 0.05 & 0.34 & 0.60 & 0.18 & 0.026 & 0.17 & 0.40 & $7.14 \mathrm{E}+06$ \\
\hline 22-Nov-10 & 0.53 & 0.35 & 0.51 & 0.75 & 0.30 & 0.04 & 0.30 & 0.55 & 0.18 & 0.025 & 0.16 & 0.38 & $6.52 \mathrm{E}+06$ \\
\hline 06-Dec-10 & 0.60 & 0.41 & 0.59 & 0.83 & 0.28 & 0.03 & 0.28 & 0.52 & 0.12 & 0.010 & 0.10 & 0.30 & $4.55 \mathrm{E}+06$ \\
\hline 13-Dec-10 & 0.64 & 0.42 & 0.65 & 0.83 & 0.29 & 0.06 & 0.28 & 0.56 & 0.07 & 0.004 & 0.06 & 0.19 & $1.88 \mathrm{E}+06$ \\
\hline
\end{tabular}




\begin{tabular}{|c|c|c|c|c|c|c|c|c|c|c|c|c|c|}
\hline 20-Dec-10 & 0.59 & 0.42 & 0.58 & 0.81 & 0.28 & 0.03 & 0.28 & 0.52 & 0.13 & 0.013 & 0.11 & 0.30 & $5.50 \mathrm{E}+06$ \\
\hline 27-Dec-10 & 0.50 & 0.33 & 0.48 & 0.72 & 0.32 & 0.04 & 0.33 & 0.58 & 0.18 & 0.033 & 0.17 & 0.38 & $7.23 E+06$ \\
\hline 03-Jan-11 & 0.56 & 0.39 & 0.54 & 0.77 & 0.29 & 0.04 & 0.29 & 0.53 & 0.16 & 0.023 & 0.14 & 0.34 & $6.31 \mathrm{E}+06$ \\
\hline 24-Jan-11 & 0.59 & 0.43 & 0.58 & 0.79 & 0.26 & 0.03 & 0.27 & 0.49 & 0.14 & 0.020 & 0.13 & 0.32 & $5.63 E+06$ \\
\hline 08-Mar-11 & 0.52 & 0.34 & 0.51 & 0.76 & 0.32 & 0.04 & 0.33 & 0.58 & 0.16 & 0.019 & 0.14 & 0.36 & $6.49 \mathrm{E}+06$ \\
\hline 05-May-11 & 0.46 & 0.27 & 0.44 & 0.70 & 0.29 & 0.03 & 0.29 & 0.57 & 0.25 & 0.037 & 0.23 & 0.52 & $6.43 E+06$ \\
\hline 18-Jul-11 & 0.61 & 0.40 & 0.60 & 0.84 & 0.29 & 0.04 & 0.29 & 0.54 & 0.10 & 0.008 & 0.08 & 0.26 & $3.97 \mathrm{E}+06$ \\
\hline
\end{tabular}


TABLE S8: TRMM-meteorological station rainfall regressions used to estimate rainfall

\begin{tabular}{clll}
\hline $\begin{array}{l}\text { Station number } \\
\text { (Figure 1a) }\end{array}$ & $\begin{array}{l}\text { Meteorological } \\
\text { station name }\end{array}$ & Rainfall estimate $\left(\mathrm{mm} \text { month }^{-1}\right)^{*}$ & $r^{2}$ \\
\hline 1 & Acjanaco & $0.8395 \times \mathrm{TRMM}+35.315$ & 0.73 \\
2 & 3450 TU & $1.1091 \times \mathrm{TRMM}+58.255$ & 0.89 \\
3 & Wayqecha & $0.6606 \times \mathrm{TRMM}+43.022$ & 0.67 \\
4 & 2750 TU & $1.239 \times \mathrm{TRMM}+93.704$ & 0.84 \\
5 & Rocotal & $1.264 \times \mathrm{TRMM}+173.4$ & 0.31 \\
6 & $1800 \mathrm{TU}$ & $1.1793 \times \mathrm{TRMM}+172.08$ & 0.79 \\
7 & San Pedro & $1.354 \times \mathrm{TRMM}+217.35$ & 0.73 \\
8 & 1500 SP & $1.6807 \times \mathrm{TRMM}+203.07$ & 0.83 \\
9 & Chontachaca & $1.183 \times \mathrm{TRMM}+276.69$ & 0.63 \\
\hline
\end{tabular}

${ }^{*}$ Wind-induced rainfall loss is not included in these equations, which would add approximately $2.5 \%$ to these rainfall measures.

443 
TABLE S9: Water isotope data of stream water collected from the Kosñipata River at the Wayqecha gauging station

\begin{tabular}{|c|c|c|c|c|c|c|}
\hline $\begin{array}{l}\text { Date and hour } \\
\text { (dd-mmm-yy hr) }\end{array}$ & $\delta^{18} \mathrm{O}(\% 0)$ & $\begin{array}{c}\sigma \delta^{18} \mathrm{O} \\
(\% 0)\end{array}$ & $\begin{array}{l}\delta D \\
(\%)\end{array}$ & $\begin{array}{c}\sigma \delta D \\
(\%)\end{array}$ & Dxs & $\sigma D x s$ \\
\hline 29-Jan-10 09 & -13.93 & 0.16 & -98.40 & 0.74 & 13.03 & 1.46 \\
\hline 29-Jan-10 15 & -14.02 & 0.16 & -98.93 & 0.22 & 13.24 & 1.28 \\
\hline 30-Jan-10 03 & -14.33 & 0.16 & -101.49 & 0.29 & 13.13 & 1.30 \\
\hline 30-Jan-10 09 & -14.17 & 0.16 & -100.22 & 0.54 & 13.11 & 1.37 \\
\hline 30-Jan-10 15 & -14.21 & 0.16 & -99.83 & 0.27 & 13.81 & 1.29 \\
\hline 31-Jan-10 03 & -14.08 & 0.16 & -99.04 & 0.72 & 13.61 & 1.45 \\
\hline 31-Jan-10 15 & -13.85 & 0.16 & -98.16 & 0.66 & 12.62 & 1.42 \\
\hline 01-Feb-10 15 & -13.83 & 0.16 & -97.25 & 0.86 & 13.38 & 1.52 \\
\hline 01-Feb-10 21 & -13.84 & 0.16 & -96.81 & 0.47 & 13.88 & 1.34 \\
\hline 02-Feb-10 03 & -13.85 & 0.16 & -97.03 & 0.84 & 13.81 & 1.51 \\
\hline 02-Feb-10 15 & -13.67 & 0.16 & -96.45 & 0.77 & 12.92 & 1.47 \\
\hline 03-Feb-10 03 & -13.77 & 0.16 & -97.41 & 0.53 & 12.76 & 1.36 \\
\hline 03-Feb-10 09 & -13.74 & 0.16 & -96.05 & 1.16 & 13.85 & 1.70 \\
\hline 03-Feb-10 15 & -13.73 & 0.16 & -96.48 & 0.38 & 13.37 & 1.31 \\
\hline 04-Feb-10 03 & -13.75 & 0.16 & -96.33 & 0.29 & 13.71 & 1.28 \\
\hline 04-Feb-10 09 & -13.80 & 0.16 & -96.08 & 0.93 & 14.29 & 1.56 \\
\hline 04-Feb-10 15 & -13.65 & 0.16 & -95.33 & 0.27 & 13.83 & 1.28 \\
\hline 04-Feb-10 21 & -13.75 & 0.16 & -96.22 & 0.33 & 13.79 & 1.29 \\
\hline 05-Feb-10 09 & -13.80 & 0.16 & -96.72 & 0.84 & 13.66 & 1.51 \\
\hline 05-Feb-10 15 & -13.87 & 0.16 & -97.55 & 0.58 & 13.43 & 1.38 \\
\hline 05-Feb-10 21 & -13.76 & 0.16 & -96.59 & 0.32 & 13.51 & 1.29 \\
\hline 06-Feb-10 03 & -13.81 & 0.16 & -96.85 & 1.15 & 13.61 & 1.70 \\
\hline 06-Feb-10 09 & -13.63 & 0.16 & -96.75 & 0.16 & 12.33 & 1.26 \\
\hline 06-Feb-10 15 & -13.68 & 0.16 & -96.55 & 0.21 & 12.92 & 1.27 \\
\hline 06-Feb-10 21 & -13.80 & 0.16 & -96.14 & 0.23 & 14.27 & 1.27 \\
\hline 07-Feb-10 03 & -13.70 & 0.16 & -96.27 & 0.76 & 13.37 & 1.46 \\
\hline 07-Feb-10 09 & -13.73 & 0.16 & -96.22 & 0.24 & 13.59 & 1.27 \\
\hline 07-Feb-10 15 & -13.70 & 0.16 & -96.26 & 0.05 & 13.36 & 1.25 \\
\hline 07-Feb-10 21 & -13.74 & 0.16 & -96.25 & 0.73 & 13.63 & 1.45 \\
\hline 08-Feb-10 03 & -13.65 & 0.16 & -95.85 & 0.42 & 13.37 & 1.32 \\
\hline 08-Feb-10 09 & -13.73 & 0.16 & -96.81 & 0.74 & 12.99 & 1.45 \\
\hline 08-Feb-10 21 & -13.68 & 0.16 & -96.28 & 0.18 & 13.19 & 1.26 \\
\hline 09-Feb-10 03 & -13.65 & 0.16 & -95.84 & 0.16 & 13.33 & 1.26 \\
\hline 09-Feb-10 09 & -13.87 & 0.16 & -97.70 & 0.39 & 13.26 & 1.31 \\
\hline 09-Feb-10 15 & -13.71 & 0.16 & -96.45 & 0.46 & 13.20 & 1.33 \\
\hline 09-Feb-10 21 & -13.75 & 0.16 & -96.34 & 0.19 & 13.62 & 1.26 \\
\hline 10-Feb-10 03 & -13.77 & 0.16 & -96.28 & 1.26 & 13.86 & 1.78 \\
\hline 10-Feb-10 09 & -13.68 & 0.16 & -96.19 & 0.16 & 13.24 & 1.26 \\
\hline 10-Feb-10 15 & -13.70 & 0.16 & -96.43 & 0.55 & 13.15 & 1.36 \\
\hline 10-Feb-10 21 & -13.47 & 0.16 & -94.13 & 0.26 & 13.66 & 1.27 \\
\hline 11-Feb-10 15 & -13.66 & 0.16 & -95.57 & 0.39 & 13.69 & 1.31 \\
\hline 11-Feb-10 21 & -13.50 & 0.16 & -94.56 & 0.53 & 13.45 & 1.35 \\
\hline 22-Feb-10 & -13.81 & 0.16 & -98.09 & 0.05 & 12.38 & 1.25 \\
\hline
\end{tabular}


TABLE S9, cont.: Water isotope data of stream water collected from the Kosñipata River at the Wayqecha gauging station

\begin{tabular}{lcccccc}
\hline $\begin{array}{l}\text { Date and hour } \\
\text { (dd-mmm-yy hr) }\end{array}$ & $\delta^{18} \mathrm{O}(\%)$ & $\begin{array}{c}\sigma \delta^{18} \mathrm{O} \\
(\%)\end{array}$ & $\begin{array}{c}\delta \mathrm{D} \\
(\%)\end{array}$ & $\begin{array}{c}\sigma \delta \mathrm{D} \\
(\%)\end{array}$ & Dxs & $\sigma \mathrm{Dxs}$ \\
\hline 01-Mar-10 & -13.83 & 0.16 & -97.81 & 0.57 & 12.86 & 1.37 \\
05-Apr-10 & -13.58 & 0.16 & -95.45 & 0.27 & 13.22 & 1.27 \\
12-Apr-10 & -13.57 & 0.16 & -95.24 & 0.24 & 13.31 & 1.27 \\
19-Apr-10 & -13.23 & 0.15 & -93.21 & 0.37 & 12.62 & 1.29 \\
10-May-10 & -13.45 & 0.16 & -94.45 & 0.13 & 13.16 & 1.25 \\
16-May-10 & -13.33 & 0.15 & -93.77 & 0.25 & 12.85 & 1.27 \\
07-Jun-10 & -13.31 & 0.15 & -93.80 & 0.33 & 12.71 & 1.28 \\
28-Jun-10 & -12.83 & 0.15 & -88.97 & 0.37 & 13.66 & 1.29 \\
11-Jul-10 & -13.05 & 0.15 & -90.93 & 0.17 & 13.44 & 1.25 \\
26-Jul-10 & -13.07 & 0.15 & -91.66 & 0.50 & 12.89 & 1.33 \\
22-Aug-10 & -13.05 & 0.15 & -91.25 & 0.30 & 13.14 & 1.27 \\
29-Aug-10 & -13.10 & 0.15 & -90.49 & 0.31 & 14.29 & 1.27 \\
25-Oct-10 & -12.89 & 0.15 & -89.90 & 0.34 & 13.21 & 1.28 \\
20-Dec-10 & -13.20 & 0.15 & -91.93 & 0.25 & 13.64 & 1.26 \\
03-Jul-11 & -13.37 & 0.16 & -94.66 & 0.67 & 12.29 & 1.41 \\
18-Feb-11 & -13.81 & 0.16 & -96.92 & 0.28 & 13.58 & 1.28 \\
21-Mar-11 & -14.01 & 0.16 & -99.00 & 0.51 & 13.09 & 1.36 \\
\hline Mean isotope values and $\sigma$ (standard deviation) were from 3 replicate sample \\
injections (see description of methods in Supplementary Text) & & \\
\# hour not reported when only one sample collected on a given date & \\
\hline & & & & & & \\
\hline
\end{tabular}


TABLE S10: Results for the Kosñipata catchment at the Wayqecha (WQ) gauging station.

\begin{tabular}{|c|c|c|c|c|}
\hline & $Q\left(m^{3} s^{-1}\right)$ & Runoff, $\mathrm{mm} \mathrm{d}^{-1}(\%)$ & $\begin{array}{c}\text { Catchment wide } \\
\text { Rainfall^ } \mathrm{mm} \mathrm{d}^{-1}(\%)\end{array}$ & $\begin{array}{l}\text { Catchment wide } \\
\text { AET } \mathrm{mm} \mathrm{d}^{-1}(\%)\end{array}$ \\
\hline Wet & 8.0 & $14.1(56.5)$ & $12.9(62)$ & $1.6(31)$ \\
\hline Wet-dry & 7.8 & $14.4(13.5)$ & $5.4(6.5)$ & $1.7(7.8)$ \\
\hline Dry & 2.3 & $4.1(21)$ & 3.1 (18) & $1.6(38)$ \\
\hline Dry-wet & 2.6 & $4.6(9)$ & $5.6(13.5)$ & $1.9(18)$ \\
\hline Annual & 4.7 & $8.4(100)$ & $6.9(100)$ & $1.8(100)$ \\
\hline
\end{tabular}

Seasonal contribution as percentage of total annual in parenthesis.

$\wedge$ Catchment-wide rainfall is reported for February 2010 to January 2011 and includes wind-induced rainfall loss (Table S3) and with the contribution from each season as a percentage in parenthesis. 


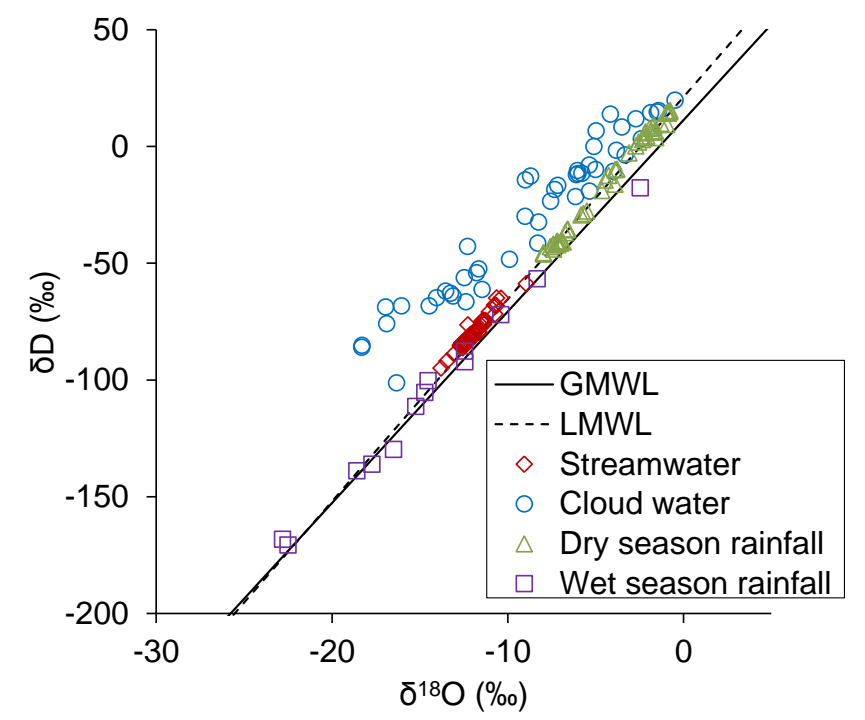

451

452 Figure $\mathrm{S} 1$ : Hydrogen isotope ratio $\left(\delta \mathrm{D}, \%\right.$ ) plotted versus oxygen isotope ratio $\left(\delta^{18} \mathrm{O}, \% \mathrm{o}\right)$ of

454 the Kosñipata catchment. Rainwater samples are from the dry season (May to August, green

455 triangles) and the wet season (December to March, purple squares). The global meteoric

456 water line (GMWL, $\delta \mathrm{D}=8.20 \times \delta^{18} \mathrm{O}+11.27$ ) is shown as the solid line (Rozanski et al.,

457 1993; Craig, 1961). The local meteoric water line (LMWL, $\delta \mathrm{D}=8.6561 \times \delta^{18} \mathrm{O}+21.119$ ) is

458 shown as the dashed line.

459

460 